\title{
EBV-Driven Lymphoproliferative Disorders and Lymphomas of the Gastrointestinal Tract: A Spectrum of Entities with a Common Denominator (Part 3)
}

\author{
Magda Zanelli ${ }^{1, *(\mathbb{D})}$, Francesca Sanguedolce ${ }^{2}$, Andrea Palicelli ${ }^{1}{ }^{\mathbb{D}}$, Maurizio Zizzo $^{3}$ (D), Giovanni Martino ${ }^{4} \mathbb{D}$, \\ Cecilia Caprera ${ }^{4}$, Valentina Fragliasso ${ }^{5}$ (D), Alessandra Soriano ${ }^{6}$, Fabrizio Gozzi ${ }^{7}$ (D), Luca Cimino ${ }^{7}$ (D), \\ Francesco Masia ${ }^{8}$, Marina Moretti ${ }^{8}$, Moira Foroni ${ }^{1}$, Loredana De Marco ${ }^{1}$, David Pellegrini ${ }^{4}$, \\ Hendrik De Raeve ${ }^{9,10}$, Stefano Ricci ${ }^{1}$, Ione Tamagnini ${ }^{1}$, Alessandro Tafuni ${ }^{11} \mathbb{D}$, Alberto Cavazza ${ }^{1}$, \\ Francesco Merli ${ }^{12}$, Stefano A. Pileri ${ }^{13,+}$ and Stefano Ascani ${ }^{4,+}$
}

check for updates

Citation: Zanelli, M.; Sanguedolce,

F.; Palicelli, A.; Zizzo, M.; Martino, G.; Caprera, C.; Fragliasso, V.; Soriano, A.; Gozzi, F.; Cimino, L.; et al. EBV-Driven Lymphoproliferative Disorders and Lymphomas of the Gastrointestinal Tract: A Spectrum of Entities with a Common Denominator (Part 3). Cancers 2021, 13, 6021. https://doi.org/10.3390/ cancers13236021

Academic Editors: David Wong and Hans Knecht

Received: 11 November 2021 Accepted: 28 November 2021 Published: 30 November 2021

Publisher's Note: MDPI stays neutral with regard to jurisdictional claims in published maps and institutional affiliations.

Copyright: (c) 2021 by the authors. Licensee MDPI, Basel, Switzerland. This article is an open access article distributed under the terms and conditions of the Creative Commons Attribution (CC BY) license (https:// creativecommons.org/licenses/by/ $4.0 /)$.
1 Pathology Unit, Azienda USL-IRCCS di Reggio Emilia, 42123 Reggio Emilia, Italy; andrea.palicelli@ausl.re.it (A.P.); moira.foroni@ausl.re.it (M.F.); loredana.demarco@ausl.re.it (L.D.M.); stefano.ricci@ausl.re.it (S.R.); ione.tamagnini@ausl.re.it (I.T.); alberto.cavazza@ausl.re.it (A.C.)

2 Pathology Unit, Policlinico Riuniti, University of Foggia, 71122 Foggia, Italy; francesca.sanguedolce@unifg.it

3 Surgical Oncology Unit, Azienda USL-IRCCS di Reggio Emilia, 42123 Reggio Emilia, Italy; maurizio.zizzo@ausl.re.it

4 Pathology Unit, Azienda Ospedaliera Santa Maria di Terni, University of Perugia, 05100 Terni, Italy; gio.martino@gmail.com (G.M.); ceciliacaprera@libero.it (C.C.); d.pellegrini@aospterni.it (D.P.); s.ascani@aospterni.it (S.A.)

5 Laboratory of Translational Research, Azienda USL-IRCCS di Reggio Emilia, 42123 Reggio Emilia, Italy; valentina.fragliasso@ausl.re.it

6 Gastroenterology Division, Azienda USL-IRCCS di Reggio Emilia, 42123 Reggio Emilia, Italy; alessandra.soriano@ausl.re.it

7 Ocular Immunology Unit, Azienda USL-IRCCS di Reggio Emilia, 42123 Reggio Emilia, Italy; fabrizio.gozzi@ausl.re.it (F.G.); luca.cimino@ausl.re.it (L.C.)

8 Dipartimento di Medicina, Università degli Studi di Perugia, 05100 Terni, Italy; francesco.masia@unipg.it (F.M.); marina.moretti@unipg.it (M.M.)

9 Pathology, University Hospital Brussels, 1090 Brussels, Belgium; hendrik.de.raeve@olvz-aalst.be

10 Pathology, O.L.V. Hospital Aalst, 9300 Aalst, Belgium

11 Pathology Unit, Department of Medicine and Surgery, University of Parma, 43121 Parma, Italy; alessandro.tafuni@unipr.it

12 Hematology Unit, Azienda USL-IRCCS di Reggio Emilia, 42123 Reggio Emilia, Italy; francesco.merli@ausl.re.it

13 Haematopathology Division, European Institute of Oncology-IEO IRCCS Milan, 20141 Milan, Italy; stefano.pileri@unibo.it

* Correspondence: magda.zanelli@ausl.re.it; Tel.: +39-0522-296-532

$+\quad$ The last two Authors equally contributed.

Simple Summary: The Epstein-Barr virus (EBV) is a commonly occurring virus, infecting more than $90 \%$ of the world population, often early in life. However, only a minority of individuals develop EBVdriven diseases at some point in their lifetime. EBV is associated with several neoplasms including epithelial, mesenchymal and lymphoid tumors. EBV-driven lymphoid proliferations encompass a wide spectrum of diseases with different biological behaviors, developing frequently, although not always, in conditions of immunosuppression. The diagnosis is often complicated and requires a strict combination of clinical, pathological and molecular findings. The aim of this review, divided into three parts, is to provide an update on EBV-driven lymphoproliferative disorders arising in the gastrointestinal tract. In this review, we discuss the chronic active EBV infection of T-cell and NK-cell type, its systemic form; extranodal NK/T-cell lymphoma, nasal type and post-transplant lymphoproliferative disorders.

Abstract: EBV is the first known oncogenic virus involved in the development of several tumors. The majority of the global population are infected with the virus early in life and the virus persists throughout life, in a latent stage, and usually within B lymphocytes. Despite the worldwide diffusion of EBV infection, EBV-associated diseases develop in only in a small subset of individuals often when 
conditions of immunosuppression disrupt the balance between the infection and host immune system. EBV-driven lymphoid proliferations are either of B-cell or $\mathrm{T} / \mathrm{NK}$-cell origin, and range from disorders with an indolent behavior to aggressive lymphomas. In this review, which is divided in three parts, we provide an update of EBV-associated lymphoid disorders developing in the gastrointestinal tract, often representing a challenging diagnostic and therapeutic issue. Our aim is to provide a practical diagnostic approach to clinicians and pathologists who face this complex spectrum of disorders in their daily practice. In this part of the review, the chronic active EBV infection of T-cell and NK-cell type, its systemic form; extranodal NK/T-cell lymphoma, nasal type and post-transplant lymphoproliferative disorders are discussed.

Keywords: Epstein-Barr virus; chronic active EBV infection; extranodal NK/T-cell lymphoma; nasal type; post-transplant lymphoproliferative disorders

\section{Introduction}

EBV is a gamma herpesvirus that preferentially infects B lymphocytes via the CD21 cell surface protein [1-11]. Once EBV infection occurs, the virus cannot be eradicated, persisting in a latent phase within B cells throughout life.

EBV has been demonstrated to contribute to the development of different types of tumors. Epithelial cells, mesenchymal cells and lymphocytes of B, T, and NK-cell origin may be infected by EBV. Although T-lymphocytes and NK-cells may be the target of virus, the specific receptor leading to EBV infection in these cell types remains unknown [12-15].

Under conditions of immunosuppression (IS), altering the balance between the virus and the host immune response, infected cells may proliferate, causing different types of tumors, including a wide range of EBV-related lymphoproliferative disorders (LPDs) [11].

In western countries, B lymphocytes are the predominantly infected cells, often leading to LPDs of B-cell origin, whereas in Asia and central/south America, T- and NK-cells are more often infected.

EBV-linked LPDs may occur not only under circumstances of IS. Apparently immunocompetent individuals may develop a chronic disease characterized by prolonged infectious mononucleosis (IM)-like symptoms and a high EBV DNA load in the peripheral blood (PB), which is called a chronic active EBV (CAEBV) infection, mainly of T/NK-cell type and, in a minority of cases $(2 \%)$, of B-cell type [8,12-15].

Our review summarizes the current knowledge on EBV-associated LPDs involving the gastrointestinal tract (GIT) with the aim of increasing our awareness on this heterogeneous group of diseases that often present overlapping clinical and morphological features, despite different biological behavior, hence, deserving the attention of both pathologists and clinicians.

The review consists of three parts. In part 1 and 2 we analyzed the clinicopathologic features of LPDs of B-cell origin such as an Epstein-Barr virus mucocutaneous ulcer (EBVMCU) [8,16-33], EBV-positive diffuse large B-cell lymphoma not otherwise specified (EBV-positive DLBCL, NOS) [8,34-42], classic Hodgkin lymphoma (cHL) [8,43-55], plasmablastic lymphoma (PBL) [8,56-74], extra-cavitary primary effusion lymphoma (ECPEL) [8,75-92], and a Burkitt lymphoma (BL) [8,93-108].

In this part of the review, we discuss the CAEBV infection of T-cell and NK-cell type, its systemic form, extranodal NK/T-cell lymphoma, nasal type (ENKTL-NT) and EBV-associated post-transplant lymphoproliferative disorders (PTLDs).

\section{CAEBV of T-Cell and NK-Cell Type, Systemic Form}

\subsection{General Features and Etiology}

CAEBV was originally referred to as chronic IM and is characterized by persistent (IM)-like symptoms after acute EBV infection [8,12-15,109-120]. 
In primary EBV infections, presenting as IM, symptoms such as fever and lymphadenopathy usually resolve within a few weeks, although they may persist even longer and the level of EBV DNA in PB usually remains high for the first month of disease.

Infrequently, patients are unable to control EBV infection and, as a result, develop a chronic course of the disease. This course of the disease is referred to as the CAEBV disease [8,109-116].

Initially, the required duration of symptoms for the classification of CAEBV was more than six months [111].

Currently, according to the 2017 WHO classification, the diagnostic criteria for CAEBV of T-cell and NK-cell type, systemic form are as follows: (1) IM-like symptoms lasting more than three months; (2) increased EBV DNA ( $>10^{2.5}$ copies $/ \mathrm{mg}$ ) in PB; (3) histological evidence of organ disease; (4) occurrence of EBV RNA or viral protein in lymphocytes of involved tissues.

The guidelines define CAEBV of T-cell and NK-cell type, and its systemic form as a disease distinct from known conditions of immunosuppression (IS). The disease affects immunocompetent hosts, without apparent causes of IS, tumors or autoimmune diseases [8,109-116].

In the current WHO classification, CAEBV is categorized among EBV-positive T-cell and NK-cell lymphoproliferative diseases of childhood and is defined as a polyclonal, oligoclonal or frequently monoclonal LPD. Most CAEBV cases are reported in Asia (Japan, Korea, China and Taiwan), although the disease is even observed in individuals from Latin America [8]. In Western countries, the incidence is much lower and, unlike CAEBV in Asia, where EBV is detected in T-cells or NK-cells, in Western countries, EBV is detected in B lymphocytes [8,112]. Genetic polymorphism in genes related to EBV immune response has been hypothesized for the strong racial predisposition of CAEBV [8]. An impairment of EBV-specific cytotoxic T-lymphocytes activity is found in CAEBV patients [8].

The disease affects children and adolescents more frequently, although it is reported in adults $[8,113]$. Persistent fever, hepatosplenomegaly and lymphadenopathy represent the IM-like symptoms occurring in $50 \%$ of patients. EBV-infected cells may infiltrate almost any organ, resulting in organ failure.

The main clinical feature of the disease is inflammation, whereas solid masses are rarely detected. Common manifestations include severe mosquito bite allergy (SMBA), skin rash, hydroa vacciniforme (HV)-like eruptions, diarrhea and uveitis. However, as almost any organ may be involved, the clinical presentation is variable, and often delays the correct diagnosis. The clinical course varies from a prolonged course even of years to a rapid and aggressive course. Patients with NK-cell disease show skin rash, hypersensitivity to mosquito bites and mild systemic symptoms with a prolonged course, whereas in patients whose T-cells are predominantly infected, systemic symptoms are severe with rapid disease progression $[8,114]$. Severe and often fatal complications such as hemophagocytic lymphohistiocytosis (HLH), multi-organ failure and progression to overt leukemia/lymphoma may occur $[8,115,116]$. Approximately $16 \%$ of CAEBV patients develop NK/T-cell lymphoma or aggressive NK-cell leukemia $[8,116]$.

Among major laboratory findings, there are signs of liver dysfunction and pancytopenia. Elevated levels of IgG and even IgA antibodies against EBV viral capsid antigen (VCA) or early antigen (EA) are often detected. By definition, high levels of EBV DNA in PB are always present and more specific than high titres of EBV antibodies. NK-cell CAEBV shows high levels of IgE and often lower titres of anti-EBV antibodies compared with T-cell CAEBV cases which often displays high levels of EBV-specific antibodies.

\section{2. $C A E B V$ and GIT}

The involvement of GIT in CAEBV is rare, with only a few cases reported so far, and is extremely difficult to distinguish from inflammatory bowel disease (IBD) [117-120].

Patients are often young adults [118-120]. GI symptoms include vomiting, diarrhea, hematochezia and abdominal pain, which may be associated with extra-gastrointestinal 
manifestations. Acute or intermittent fever is observed in almost all patients with GI CAEBV, whereas hepatomegaly, splenomegaly and lymphadenopathy are observed in approximately half the cases.

Laboratory findings include extremely high levels of ferritin associated with increased levels of inflammatory markers such as C-reactive protein (CRP) and the erythrocyte sedimentation rate (ESR). Increased EBV DNA $\left(>10^{2.5}\right.$ copies $/ \mathrm{mg}$ ) is always detected in PB.

Endoscopy shows single or multiple ulcers mainly located in the colon and, in decreasing order of frequency, in the small intestine and stomach. Radiology may identify a thickening of the gastric or intestinal wall and/or enlarged mesenteric lymph nodes [120].

In GI CAEBV, the histological features are rather subtle and easily overlooked, unless evaluated in combination with the clinical history and laboratory data.

\subsection{Histology, Immunophenotype and Genetic Profile}

The main difficulty in diagnosing CAEBV is in the lack of changes observed, suggestive of malignancy in the affected tissues.

CAEBV histology often resembles nonspecific inflammatory changes; hence, it is essential to consider the whole clinical history and, in cases of sustained inflammation of unknown origin, CAEBV should always be taken into consideration. The identification of EBV infection by in situ hybridization for EBV-encoded RNA (EBER) in affected tissues is required to confirm the diagnosis. Lymph node histology often shows nonspecific features, including follicular hyperplasia, paracortical hyperplasia, epitheliod granulomas, focal necrosis and polymorphic infiltrate in the interfollicular zones. Red-pulp congestion and white-pulp atrophy are common, but otherwise nonspecific, findings observed in the spleen. Depending on the affected organs, CAEBV mimics viral hepatitis, viral myocarditis, interstitial pneumonia or dermatitis. Bone marrow (BM) is usually unremarkable. If HLH complicates CAEBV, features of hemophagocytosis may be observed particularly in BM, liver and lymph nodes.

In GI CAEBV, morphologic changes are often subtle. Ischemic features and erosions are frequently observed, whereas crypt abscesses are usually absent [120]. The infiltrate involving the mucosa and occasionally the submucosa and muscle layers consists of small to medium-sized lymphocytes either lacking atypia or with a mild to moderate degree of atypia. Lymphoid aggregates are observed in some cases and lymphocytes may show increased cytoplasm compared with mature small lymphocytes [120]. Focal necrosis may also be present.

EBER is the gold standard to demonstrate EBV infection, although the percentage of EBER-positive cells required for the definition of EBV infection is not well defined. Some studies suggest a requirement of at least 30 EBER positive cells/high power fields (HPF) in biopsy samples and more than 100 EBER positive cells/HPF in surgical specimens [118-120].

EBER-positive cells are predominantly of T-cell origin in 59\% of cases, mostly with a CD4 phenotype, although CD8-positive CAEBV cases are reported [120]; in $41 \%$ of cases, NK cells are infected, whereas in a low percentage of CAEBV cases (4\%) both T- and NK-cells are affected. B-cells are rarely involved (2-3\%) although usually in the Western population [112]. EBV-infected cells express EBNA1, LMP1 and LMP2A, indicating a latency pattern type 2 .

T-cell receptor (TCR) gene rearrangement indicates monoclonality in the majority of CAEBV cases ( $84 \%$ ), oligoclonality in $11 \%$ and polyclonality in only $5 \%$ of cases [121].

Based on the cytology and clonality of the lymphoid cells, the current WHO classification adopts a subdivision into different categories. Polymorphic and polyclonal proliferation are classified as A1; A2 is polymorphic and monoclonal and A3 is monomorphic and monoclonal. This classification reflects the spectrum of diseases under the umbrella term of CAEBV, from LPDs (A1-A2) to frank lymphomas (A3). The B category includes monomorphic and monoclonal cases with a fulminant course, equivalent to systemic EBV-positive T-cell lymphoma of childhood [8,122]. 


\subsection{Differential Diagnosis}

In patients suffering from a sustained inflammation of unknown origin, CAEBV should be considered. Clinicians' awareness of this rare disease is indeed the first diagnostic step to recognize CAEBV. Then, PB tests such as anti-VCA-IgG, anti-EA-IgG, anti-VCA-IgA, anti-EA-IgA together with quantification of EBV DNA load in PB should be performed. The acute phase of primary infection, that is, IM, should be excluded, checking the patient's clinical history. Anti-VCA IgM are usually present in acute IM, unlike in CAEBV.

In the absence of the clinical suspicion of CAEBV, a histological diagnosis is practically impossible as CAEBV mimics nonspecific inflammatory processes.

GI CAEBV needs to be differentiated from IBD, ENKTL-NT and EBVMCU.

A differential diagnosis from IBD can be challenging, especially considering that there are cases of IBD superimposed with EBV infection. If CAEBV is limited to the GIT, and lacks more characteristic features such as lymphadenopathy, splenomegaly and hepatomegaly, differentiating IBD from CAEBV can be very difficult. GI symptoms and increased levels of inflammatory markers (ESR and CRP) are present in both diseases. However, useful clues more in favor of CAEBV are intermittent high fever and extremely high level of ferritin [118]. Endoscopically, the cobblestone appearance observed in Crohn's disease and the diffuse and continuous GI involvement typical of ulcerative colitis are absent in CAEBV. EBV DNA in PB may be positive even in IBD patients, although usually with lower values compared to CAEBV. EBER-positive cells may be found in IBD samples; therefore, the presence of EBER-positive cells alone is not enough to diagnose CAEBV. A high index of suspicion is required if the clinical history and laboratory data are consistent with CAEBV.

Unlike CAEBV, ENKTL-NT is classically localized in the upper aerodigestive tract and then, in the course of thr disease, disseminates to other sites including the GIT. In some cases, ENKTL-NT may occur primarily in the GIT, usually presenting with perforation or GI bleeding. The angiocentric and angiodestructive pattern of growth of the lymphoid infiltrate associated with coagulative necrosis is an helpful clue in the differential with CAEBV. The main lymphoproliferative disorders of T/NK-cell origin involving the GIT are summarized in Table 1.

Table 1. Lymphoproliferative disorders of T/NK-cell origin with GIT involvement.

\begin{tabular}{|c|c|c|c|c|c|}
\hline Variation & ENKTL-NT & CAEBV & EATL & MEITL & ITLPD \\
\hline $\begin{array}{l}\text { Sites of GIT } \\
\text { (in order of } \\
\text { frequency) }\end{array}$ & $\begin{array}{c}\text { Small bowel Large } \\
\text { bowel } \\
\text { Stomach } \\
\text { Esophagus }\end{array}$ & $\begin{array}{l}\text { Large bowel } \\
\text { Small bowel } \\
\text { Stomach }\end{array}$ & $\begin{array}{c}\text { Small bowel; Large } \\
\text { bowel } \\
\text { Stomach }\end{array}$ & $\begin{array}{l}\text { Small bowel; large } \\
\text { bowel; stomach }\end{array}$ & $\begin{array}{c}\text { All sites of GIT; } \\
\text { Small bowel or } \\
\text { large bowel (more } \\
\text { often) }\end{array}$ \\
\hline $\begin{array}{l}\text { Macroscopic } \\
\text { features }\end{array}$ & $\begin{array}{l}\text { Mucosal ulcer or } \\
\text { ulcerating mass }\end{array}$ & Ulcer & $\begin{array}{l}\text { Ulcerating lesion } \\
\text { or stricture }\end{array}$ & Tumor mass & $\begin{array}{l}\text { Subtle features: } \\
\text { hyperaemic } \\
\text { mucosa; } \\
\text { nodularity; } \\
\text { Prominent folds; } \\
\text { polyps }\end{array}$ \\
\hline Coeliac disease & No & No & Yes & No & No \\
\hline Histology & $\begin{array}{c}\text { Cells of variable } \\
\text { size; } \\
\text { Admixed } \\
\text { inflammation; } \\
\text { Necrosis; } \\
\text { Angioinvasive/ } \\
\text { angiocentric } \\
\text { pattern }\end{array}$ & $\begin{array}{l}\text { Infiltrate within } \\
\text { mucosa, rarely } \\
\text { submucosa or } \\
\text { muscle layer } \\
\text { involvement; } \\
\text { Small/medium- } \\
\text { sized cells often } \\
\text { with mild atypia }\end{array}$ & $\begin{array}{c}\text { Medium/ } \\
\text { large- } \\
\text { sized cells; } \\
\text { Admixed } \\
\text { inflammation; } \\
\text { Necrosis; } \\
\text { Angioinvasive/ } \\
\text { angiocentric } \\
\text { pattern }\end{array}$ & $\begin{array}{l}\text { Monomorphic } \\
\text { Medium- } \\
\text { Sized cells; } \\
\text { Epitheliotropism } \\
\text { (often) }\end{array}$ & $\begin{array}{l}\text { Non-destructive } \\
\text { mucosal infiltrate } \\
\text { (rarely muscolaris } \\
\text { mucosae or } \\
\text { submucosa } \\
\text { involved) }\end{array}$ \\
\hline
\end{tabular}


Table 1. Cont.

\begin{tabular}{|c|c|c|c|c|c|}
\hline Variation & ENKTL-NT & CAEBV & EATL & MEITL & ITLPD \\
\hline Cell of origin & $\begin{array}{l}\text { NK-cell often; } \\
\text { T-cell }\end{array}$ & $\begin{array}{l}\text { T-cell (59\%); } \\
\text { NK-cell (41\%); } \\
\text { B-cell rarely }\end{array}$ & T-cell & T-cell & T-cell \\
\hline IHC & $\begin{array}{c}\text { NK cell origin: } \\
\text { CD2+ cCD3+ } \\
\text { CD56- cytotoxic } \\
\text { molecules+ } \\
\text { CD7+/- } \\
\text { CD30+/- sCD3-, } \\
\text { CD4- CD8- } \\
\text { CD5- CD16- } \\
\text { CD57- MATK+. } \\
\text { T-cell origin: } \\
\text { sCD3+ CD5+ CD8+ } \\
\text { MATK+ }\end{array}$ & $\begin{array}{l}\text { T-cell origin: } \\
\text { CD4 > CD8 }\end{array}$ & $\begin{array}{c}\text { CD3+ CD7+ } \\
\text { CD103+ CD5- } \\
\text { CD4- } \\
\text { CD8- often } \\
\text { cytotoxic } \\
\text { molecules+ } \\
\text { CD30+ (often) } \\
\text { TCRB+ (in some } \\
\text { cases) } \\
\text { TCRG+ (in some } \\
\text { cases) }\end{array}$ & $\begin{array}{c}\text { CD3+ CD8+ } \\
\text { CD56+ } \\
\text { CD5- } \\
\text { TCRG+ (often) } \\
\text { TIA1+ } \\
\text { CD20 aberrant+ } \\
\text { (20\% of cases) } \\
\text { MATK+ }\end{array}$ & $\begin{array}{c}\text { CD3+ CD8+ often; } \\
\text { CD4+ some cases; } \\
\text { CD4- CD8- } \\
\text { rarely; } \\
\text { CD2+ CD5+ } \\
\text { CD7+/- } \\
\text { TIA1+ } \\
\text { Granzyme B- } \\
\text { TCR alfa beta+ } \\
\text { CD56- }\end{array}$ \\
\hline EBER-ISH & Positive & Positive & Negative & Negative & Negative \\
\hline $\begin{array}{l}\text { Proliferative } \\
\text { fraction }\end{array}$ & High & Low & High & High & Low \\
\hline T-cell clonality & $\begin{array}{l}\text { T-cell clonality in } \\
\text { cases of T-cell } \\
\text { origin }\end{array}$ & $\begin{array}{l}\text { T-cell clonality; } \\
\text { more rarely } \\
\text { oligoclonality or } \\
\text { polyclonality }\end{array}$ & T-cell clonality & T-cell clonality & \\
\hline Clinical course & Aggressive & $\begin{array}{c}\text { Variable (NK } \\
\text { forms: more } \\
\text { favorable course) }\end{array}$ & Aggressive & Aggressive & Indolent \\
\hline
\end{tabular}

CAEBV: chronic active Epstein-Barr virus infection; EBER-ISH: EBV-encoded RNA in situ hybridization; EATL: enteropathy-associated T-cell lymphoma; ENKTL-NT: extranodal NK/T-cell lymphoma, nasal type; gi-ITLPD: indolent T-cell lymphoproliferative disorder of the gastrointestinal tract; GIT: gastrointestinal tract; IHC: immunohistochemistry; MATK: megakaryocyte-associated tyrosine kinase; MEITL: monomorphic epitheliotropic intestinal T-cell lymphoma; TCRB: T-cell receptor beta gene rearrangement; TCRG: T-cell receptor gamma gene rearrangement.

EBVMCU is a B-cell LPD presenting with isolated ulcers in the oropharynx, skin and GIT [8]. Unlike CAEBV, which usually occurs in young adults without known immunodeficiency, EBVMCU often occurs in elderly patients or in individuals with iatrogenic IS. In EBVMCU, the ulcers frequently consist of a polymorphic infiltrate containing EBV-positive atypical cells, often resembling Hodgkin cells, with strong CD30 positivity and a variable expression of B cell markers. The disease course is completely different, as EBVMCU is an indolent disorder often regressing spontaneously or upon removal of the cause of IS, whereas CAEBV prognosis is often dismal.

\subsection{Treatment and Outcome}

The behavior of the disease is variable, depending on the EBV viral load, the host immunity and the type of the infected cells. Patients with NK-cell infection show a more favorable course with mild systemic symptoms and a 5-year survival rate of $87 \%$ compared with T-cell CAEBV patients, who experience a more aggressive course with a survival rate of $59 \%[8,113]$. CAEBV patients with adult onset of disease show a worse outcome $[8,113]$. If complications such as HLH or lymphoma develop, CAEBV can be fatal. Therefore, treatment must begin before these serious complications occur.

To date, the only known effective cure is an allogenic hematopoietic stem cell transplant (allo-HSCT). Fifteen-year overall survival (OS) is $60.6 \%$ in patients treated with allo-HSCT compared to $25.7 \%$ in patients without allo-HSCT [121]. In addition, the OS was significantly higher (85\%) in patients receiving reduced intensity conditioning (RIC) compared to patients with myeloablative conditioning (54.5\%), indicating that the positive effect of allo-HSCT depends mainly on the reconstruction of the hematopoietic and immune 
system, rather than on the antineoplastic effect of chemotherapy (CT) and radiotherapy (RT) $[123,124]$. The outcome of CAEBV after allo-HSCT depends on the activity of the disease as patients with an active CAEBV characterized by fever, liver dysfunction, vasculitis or progressive skin lesions have a poor prognosis after allo-HSCT [121]. Poor results have been obtained with different types of CT with the aim of reducing disease activity [125].

\section{ENKTL-NT}

\subsection{General Features and Etiology}

ENKTL-NT is an aggressive, angiocentric and angiodestructive lymphoma principally affecting the nasal or upper aerodigestive tract and, more rarely, non-nasal sites.

The disease is prevalent in Asia (Japan, Korea, Taiwan, China, Hong Kong and Thailand) and Latin America (Mexico, Guatemala, Brazil) [8,126-135]; it more often affects adult males with a median age of 40-60 years, although occurrence in children is rarely reported.

EBV infection and genetic predisposition are likely to be involved in the pathogenesis, thereby explaining the characteristic ethnic distribution of this lymphoma [8,126-128]. The way EBV contributes to the genesis of the disease is still not completely clarified; possible EBV-related oncogenic mechanisms may be the overexpression of the oncogenic protein LMP1 as well as the activation of the NF-kB signaling pathway $[127,128]$.

Diverse genetic abnormalities are likely to contribute to ENKTL-NT tumorigenesis. Deletion of chromosomal region at 6q21-23, containing multiple tumor suppressor genes (PRDM1, PTPRK, FOXO3) is frequently found in ENKTL-NT (36-60\% of cases); additionally, genetic alterations of the JAK-STAT pathway and mutations involving tumor suppressor genes such as BCOR, DDX3X and TP53 have been identified [126,129-131].

Clinical manifestations vary according to the primary site of disease occurrence. The most common clinical symptoms are nasal obstruction with epistaxis, followed by necrotic lesions involving the upper aerodigestive tract and midface with an extension to contiguous areas and massive midfacial destruction $[8,126]$. Systemic symptoms such as fever and weight loss are variably present.

At diagnosis, patients usually have localized disease (stage I or II), although, during the clinical course, the involvement of other sites such as GIT, skin, lymph nodes and the central nervous system (CNS) is common. BM involvement is rare at presentation, but may occur in the clinical course. HLH is a serious complication of this lymphoma, which may develop especially in cases with BM involvement. In approximately $20-30 \%$ of cases, the disease may occur in extranasal sites such as the skin, soft tissue, testis, salivary gland, liver and GIT, causing organ-specific manifestations [8,132-135]. Although secondary nodal involvement may rarely occur, primary nodal presentation is considered very rare [136] and these cases should be better classified as a variant of peripheral T-cell lymphoma [8].

Cases occurring outside the nasal region seem to have a worse outcome than the classic nasal form and often present at advanced stages [132-135].

\subsection{ENKTL-NT and GIT}

Primary GI ENKTL-NT is rare, representing 2.7\% of ENKTL-NT [137,138]. Clinical manifestations include abdominal pain, GI bleeding, intestinal obstruction and bowel perforation, often leading to surgery.

The small intestine is most often involved, especially the ileum (29\%) and jejunum (17\%) followed by duodenum (4\%). The large bowel represents the second most common site with the right colon more frequently involved than the distal tract (cecum 14\%; ascending colon 11\%; transverse colon $9 \%$; descending colon $4 \%$; rectosigmoid colon $6 \%$ ); whereas the stomach $(5 \%)$ and the esophagus $(1 \%)$ are more rarely affected.

A discrete proportion of patients may present multiple involvement of GIT such as concomitant small and large bowel involvement. Other extranodal sites such as the nasal tract may be concomitantly involved; the majority of patients present B symptoms and the disease is often at an advanced stage at presentation. 


\subsection{Histology, Immunophenotype and Genetic Profile}

ENKTL-NT usually presents as a mucosal ulcer or an ulcerated mass. Histologically, the neoplasm consists of a diffuse infiltrate of variably sized lymphoid cells, although small to medium-sized cells, often with clear cytoplasm and irregularly folded nuclei, usually predominate. Cells of large size may be present. The neoplastic elements are generally accompanied by an abundant inflammatory component and necrosis.

An angiocentric and angiodestructive growth pattern is commonly present, although it is worth mentioning that these characteristic features may not be evident in small biopsy samples [135].

The disease is often of NK-cell origin and the neoplastic cells are usually positive for CD2, cytoplasmic CD3 (cCD3), CD56 and cytotoxic molecules (TIA1, perforin and granzyme $\mathrm{B}$ ), occasionally express $\mathrm{CD} 7$ and $\mathrm{CD} 30$, whereas they are usually negative for surface CD3 (sCD3), CD4, CD8, CD5, CD16, CD57 and lack TCR gene rearrangement. The subset of cases of cytotoxic T-cell lineage (10-40\% of cases) usually express SCD3, CD5, CD8 and show T-cell clonality. Nuclear expression of megakaryocyte-associated tyrosine kinase (MATK) is common.

EBER positivity represents a diagnostic criterion and a diagnosis of ENKTL should be considered unlikely if EBV is negative. The disease shows a type I latency pattern being often LMP1 negative. By gene expression profiling analysis, numerous oncogenic pathways have been identified to be activated in ENKTL-NT, including JAK/STAT and NF$\mathrm{kB}[127,128]$ and several recurrent genetic and epigenetic (hypermethylation) alterations have been found in ENKTL-NT [139].

\subsection{Differential Diagnosis}

ENKTL-NT diagnosis can be challenging, particularly in cases that develop in extranasal sites, such as the GIT and if the pathologist is faced with small biopsy specimens. Tumors such as ENKTL-NT with superimposed conspicuous inflammatory infiltrate may be confused with inflammatory/infectious processes $[126,140,141]$. The differential diagnosis with CAEBV has been discussed in the paragraph dedicated to CAEBV.

The presence of an angiocentric and angioinvasive pattern may resemble lymphomatoid granulomatosis (LYG), a rare EBV-driven LPD, usually developing in the setting of immunodeficiency. $[8,142,143]$. LYG essentially affects the lungs and a diagnosis of LYG without lung involvement is questionable; additionally, GI involvement in LYG is rare. In LYG, the EBV-positive atypical large cells of B-cell origin are often small in number and dispersed among numerous reactive $T$ lymphocytes. LYG shows angioinvasion by CD4-positive reactive T lymphocytes, whereas in cases of ENKTL-NT of T-cell origin, the neoplastic infiltrate is composed of CD8-positive cells.

Some EBV-negative lymphomas, which may occur in the GIT, such as indolent Tcell lymphoproliferative disorder (ITLPD), NK-cell enteropathy (NKCE), enteropathyassociated T-cell lymphoma (EATL), monomorphic epitheliotropic T-cell lymphoma (MEITL) have to be considered in the differential diagnosis $[8,144,145]$. The correct diagnosis of these entities requires attention to clinico-pathological features such as history of celiac disease, depth of lymphoid infiltrate, cytological and immunophenotypic features and association with EBV.

ITLPD of the GIT, included as a provisional entity in the current WHO classification, is a low grade clonal non-epitheliotropic LPD affecting almost any site of the GIT, particularly the small intestine and colon $[8,144,145]$. The clinical behavior is usually indolent with a chronic relapsing clinical course although cases of transformation to high grade lymphomas may occur. In ITLPD, small-sized and bland-looking T-lymphocytes involve mainly the lamina propria and sometimes extend to the muscolaris mucosae and submucosa; tumor masses and full thickness involvement are usually not present. The lymphocytes show a CD4-positive or CD8-positive phenotype, although double positive or double negative cases are seen. Characteristic findings of ENKTL-NT such as angioinvasion, angiocentricity and necrosis along with EBER and CD56 positivity are typically absent in ITLPD. 
NKCE is a rare and indolent LPD of NK cells involving the GIT. Similarly to ITLPD, the infiltrate is usually superficial and not mass-forming. Necrosis and angioinvasion are absent; the cells of medium and large size express cCD3, CD2, CD7, CD56 and cytotoxic molecules and are EBER-negative. Pathologists need to be aware of this entity in order to avoid a misdiagnosis of ENKTL-NT.

MEITL and EATL are aggressive lymphomas, and, in both diseases, patients usually present with a mass lesion leading to intestinal obstruction and perforation with consequent acute symptoms. EATL is strongly associated with celiac disease and occurs mainly in the Western population; MEITL may occur worldwide although more frequently in Asian populations and is not linked with celiac disease.

EATL consists of large, pleomorphic cells and some histological features such as the often prominent inflammatory component along with extensive necrosis and angiocentric/angioinvasive growth may be suggestive of ENKTL-NT. In EATL, the cells usually express CD3, cytotoxic molecules and CD30 and are more often negative for CD4 and CD8; EATL is CD56 and EBER negative, although admixed EBER-positive by-stander small lymphocytes may be found.

MEITL consists of monomorphic and small to medium-sized cells with a striking epitheliotropism. In contrast to both ENKTL-NT and EATL, inflammatory background, necrosis and angioinvasion are absent. MEITL shows a distinctive phenotype, and is positive for CD3, CD8 and CD56 in the majority of cases, however, pathologists need to be aware of phenotypic variation as CD8 and CD56 may be negative and the aberrant expression of CD20 may lead to a misdiagnosis of MEITL as a B-cell lymphoma. Most MEITL are positive for MATK, a marker diagnostically helpful if expressed in $>80 \%$ of cells; however, this marker alone is not useful in the differential diagnosis with ENKTL-NT, being commonly expressed even in ENKTL-NT. EBER is consistently negative in MEITL.

\subsection{Treatment and Oucome}

The prognosis of ENKTL-NT in its nasal form has recently improved due to more intensive therapeutic schemes. The extranasal form shows a worse outcome with poor response to therapy.

When localized, ENKTL-NT is treated with combined chemo-radiotherapy, whereas patients with disseminated disease are usually treated with L-asparaginase-based CT such as SMILE (dexamethasone, methotrexate, ifosfamide, L-asparaginase, etoposide) regimen [135]. After L-asparaginase-based therapy, relapse occurs in around 50\% of patients with disseminated disease and, hence, there exists an urgent need for effective targeted therapy. Programmed cell death ligand 1 (PD-L1) expression has been observed in 50-80\% of ENKTL-NT patients and checkpoint inhibitors (for instance pembrolizumab and nivolumab) have been demonstrated to be effective in some patients with advanced disease $[135,146]$. Additionally, CD38, a surface molecule expressed by ENKTL-NT, seems to be of potential value for target therapy [147]. Clinical trials evaluating JAK inhibition in ENKTL-NT are ongoing. It has been suggested that anti-CD38 antibodies or JAK inhibitors, combined with L-asparaginase-based CT, may represent a promising strategy to improve the prognosis of this aggressive lymphoma [148].

\section{PTLDs}

\subsection{General Features and Etiology}

PTLDs represent a potentially fatal complication, arising as a consequence of IS after both solid organ transplant (SOT) or HSCT [8,149-153]. PTLDs may occur at any time after transplant, but the first year post-transplant is the more critical.

PTLDs include a wide spectrum of diseases ranging from benign polyclonal LPDs, usually developing early post-transplant and regressing upon reduction of immunosuppression, to aggressive lymphomas requiring CT. The majority of PTLDs are of B-cell origin (85\%) and over $80 \%$ are associated with EBV infection, whereas approximately $15 \%$ are of T-cell lineage and of these $30 \%$ are EBV-positive. 
EBV plays a critical role in the development of most PTLDs [153]. After primary EBV infection occurring early in life, in immunocompetent individuals, the EBV genome is present in a latent form within B lymphocytes [1-4]. In conditions of IS, such as in the post-transplant setting, there is a reduction of T-cell function with a consequent lack of T-cell modulation on B-cell proliferation; this leads to uncontrolled proliferation of EBVtransformed B cells and, hence, to PTLDs. In EBV-positive PTLDs, either the infection is acquired after transplant in EBV-negative recipients or a latent EBV infection is reactivated because of IS.

Risk factors include EBV-negative recipients with EBV-positive donors, young age at transplant and more intensive immunosuppressive treatment. Seronegativity at the time of transplant increases the risk of PTLD occurrence by 10-75\% [149-153]. SOT recipients aged $<10$ and $>60$ years are at increased risk of PTLD. Pediatric patients are at high risk, being often seronegative at the time of transplantation, whereas the high incidence of PTLDs at older age may be due to reduced immune surveillance. SOT recipients have higher risk $(10 \%)$ of PTLDs than HSCT recipients (1-2\%); PTLDs represent the most frequent posttransplantation malignancy in children and the second most common post-transplantation malignancy after skin tumor in adults.

The risk varies depending on the organ transplanted. Adult recipients of multi-organ, lung or intestinal transplants have a higher risk $(=/>5 \%)$; those receiving liver and heart allografts have an intermediate risk $(1-5 \%)$, whereas those receiving kidney transplant have a lower risk of PTLD development $(<1 \%)$. This difference is in part due to the degree of immunosuppressive treatment administered for different SOT. Despite HSCT recipients having a lower risk of PTLD compared to SOT recipients, PTLDs following HSCT show a more aggressive course with high mortality $[8,154]$. The occurrence of PTLD-like lesions after autologous stem cell transplantation is rare and, according to the current WHO classification, should be included among iatrogenic immunodeficiency-associated LPDs rather than among PTLDs [8]. Patients receiving SOT require life-long immunosuppressive treatment and, therefore, may develop PTLDs even in a late phase, unlike patients receiving HSCT, who stop taking immunosuppressive agents after transplant and generally develop PTLDs within the first year.

Although PTLDs are mostly EBV-linked, approximately $20 \%$ of cases are EBV-negative. Early onset PTLDs are usually EBV-positive and may arise months after transplantation, whereas late onset PTLDs arising after years are more often EBV-negative. The pathogenesis of EBV-negative forms remains unclear, although various hypotheses including other infectious agents, chronic immune triggering by the graft and hit and run EBV infection have been proposed $[155,156]$. Some studies investigating the genomic profile of PTLDs revealed that EBV-negative cases show a genomic profile similar to that of DLBCL arising in immunocompetent individuals with a greater genomic complexity than EBV-positive PTLDs [157]. Despite these differences, similarly to EBV-positive forms, some EBV-negative PTLDs respond well to a reduction of immunosuppressive treatment.

PTLD clinical presentation is variable; PTLDs may be incidentally found due to the paucity of symptoms; sometimes non-specific symptoms such as pyrexia and malaise are present, whereas in other cases the disease is fulminant with multi-organ failure. Almost any organ may be involved, although lymph nodes (33\%), GIT (29\%), central nervous system (CNS) (13\%), liver (12\%) and lung (4\%) are the sites most commonly affected [151]. In PTLDs occurring after SOT, PTLD may involve the transplanted organ, with allograft dysfunction and, therefore, the correct diagnosis may be difficult as infection and allograft rejection may cause similar clinical manifestations.

\subsection{PTLDs and GIT}

The GIT is one of the sites that is most frequently involved by PTLDs, particularly in kidney transplants $[150,158]$. Isolated GI involvement has been reported in both the pediatric population and in adults [150,159]. Isolated GI involvement was found in 19\% of 181 adult French renal transplant recipients [151]. Symptoms may be nonspecific and 
rather vague. In a large series by Cruz et al. it was noted that GI PTLDs were often of late onset, frequently involved the lower GIT (small bowel and right colon 81\%) and were more often monoclonal [160]. Intestinal obstruction represents a common indication for surgery, whereas GI bleeding and perforation are associated with a worse outcome [160].

\subsection{Histology, Immunophenotype and Genetic Profile}

Based on the criteria defined in the current WHO classification, PTLDs are subclassified into four categories: (1) Non-destructive PTLDs including plasmacytic hyperplasia (PH), florid follicular hyperplasia and IM-like PTLD; (2) Polymorphic PTLD (P-PTLD); (3) Monomorphic PTLD (M-PTLD), further sub-divided in B-cell, T-cell, NK-cell types and (4) cHL-like PTLD [8] (Table 2).

Table 2. Characteristics of PTLDs.

\begin{tabular}{|c|c|c|c|}
\hline WHO Classification & EBV Association & Time of Post-Transplant Onset & Clonality \\
\hline Non-destructive PTLD & Often EBV-positive & Often early & $\begin{array}{l}\text { Often polyclonal } \\
\text { (oligoclonality may be present) }\end{array}$ \\
\hline Polymorphic PTLD & Often EBV-positive & Often early & Often monoclonal \\
\hline $\begin{array}{l}\text { Monomorphic PTLD (B-cell } \\
\text { origin) }\end{array}$ & EBV-positive and EBV-negative & Both early and late & $\begin{array}{l}\text { B-cell clonality present; } \\
\text { sometimes T-cell clonality }\end{array}$ \\
\hline $\begin{array}{c}\text { Monomorphic PTLD (T/NK-cell } \\
\text { origin) }\end{array}$ & $\begin{array}{l}\text { T-cell origin: often EBV negative; } \\
\text { NK-cell origin: often EBV-positive }\end{array}$ & Often late & $\begin{array}{c}\text { T-cell clonality in PTLDs of T-cell } \\
\text { origin }\end{array}$ \\
\hline cHL-PTLD & Often EBV-positive & Often late & Clonality rarely detected \\
\hline
\end{tabular}

EBV: cHL: classic Hodgkin lymphoma; Epstein-Barr virus; PTLD: post-transplant lymphoproliferative disorder; WHO: World Health Organization.

Non-destructive PTLDs tend to occur at a younger age and are more frequent in individuals with no prior EBV exposure. They are by definition characterized by their preservation of underlying tissue architecture. Non-destructive PTLDs are mass-forming lesions. Lymph nodes, tonsils and adenoids are more frequently involved than other extranodal sites. PH shows plasma cells (PCs) with scattered immunoblasts (IBs); whereas IM-like lesions predominantly show IBs and occasionally Reed-Sternberg (RS)-like cells and PCs; the presence of necrosis and high mitotic activity may suggest malignancy. The histology is non-specific, so the diagnosis can be made on the basis of transplant history and the presence of EBV positivity. Non-destructive PTLDs are usually polyclonal, although oligoclonality may be detected; an analysis of episomal EBV DNA demonstrates that the virus is also polyclonal or oligoclonal.

P-PTLD represents the most common subtype in children and is mostly related to primary EBV infection. It consists of an heterogeneous population of small and mediumsized lymphocytes, PCs and IBs effacing the tissue architecture. Areas of geographical necrosis and cells resembling Reed Sternberg cells (RSCs) are frequently present. P-PTLDs do not fulfil the diagnostic criteria for any of the lymphoma types recognized in immunocompetent individuals. In P-PTLD there are numerous, variably-sized CD20-positive cells admixed with many predominantly small-sized T-cells. Many EBER-positive cells are present as well as numerous CD30-positive elements. However, in contrast to cHL, the CD30-positive RSCs express CD20 and lack CD15. P-PTLD are mostly monoclonal, although the clones are less predominant than in M-PTLD.

M-PTLDs are monoclonal proliferations fulfilling the diagnostic criteria for either B-cell or T/NK-cell neoplasms, recognized in immunocompetent hosts. The vast majority of M-PTLDs are of B-cell lineage and they resemble, both clinically and histologically, either DLBCL or, less frequently, Burkitt lymphoma (BL) or a plasma cell tumor. The small B-cell lymphomas arising in the setting of transplantation are not classified among PTLDs with the exclusion of the EBV-positive extranodal marginal zone lymphoma of mucosa-associated lymphoid tissue, arising in the skin and subcutaneous tissue $[8,161]$. The EBV-positive DLBCL, which represents the largest part of M-PTLDs, often shows a 
non-germinal center (GC) phenotype, whereas EBV-negative cases more often present a GC phenotype.

Molecular studies reveal monoclonal IGH gene rearrangements and that the EBV genetic material is also monoclonal. T-cell clonality may be detected in the M-PTLDs of B-cell type. Cytogenetic abnormalities are common in monomorphic B-cell PTLDs (72\%) compared with P-PTLDs, showing cytogenetic abnormalities in only $15 \%$ of cases. The most frequent clonal abnormalities in M-PTLDs are trisomies 9 and/or 11 followed by rearrangements of 8q24.1, 3q27 and 14q32 [8,162].

M-PTLDs of T/NK cell origin represent around 15\% of all PTLDs. Any WHO type of T/NK cell lymphomas arising in non-transplanted patients may be seen in the posttransplant setting. The majority of T-cell PTLDs are EBV negative, whereas PTLDs of NK cell origin are mainly EBV positive with EBV clonality [152]. T-cell clonality is present in M-PTLDs of T-cell origin.

c-HL PTLD is a rare form of PTLD, occurring mainly after renal transplant and is a late complication of transplantation. It is often of a mixed cellularity type and mostly EBV positive. The diagnosis of cHL PTLD should be performed in the presence of a typical morphology and phenotype; in particular CD30 and CD15 should be co-expressed $[8,163]$. Caution is advisable as RS-like cells are also present in other types of PTLDs; however, in these cases, RS-like cells are usually positive for CD45 and CD20 and negative for CD15 $[8,150,163]$.

PTLDs commonly demonstrate a type III latency pattern, although more restricted latency patterns are found.

\subsection{Differential Diagnosis}

Although a biopsy is required for PTLD diagnosis, a rise in EBV-viral titers should be considered highly suspicious for EBV-associated PTLD [164]. In any case, a complete history needs to be provided with the specimen, as a careful clinicopathological correlation is essential for PTLD diagnosis. A clear separation among the different PTLD categories is not always possible as they are likely to represent a pathological spectrum.

The histology, in particular of non-destructive PTLDs, is non-specific and a full patient's history is essential.

PH may simulate a plasma cell neoplasm, but PH is polyclonal. IM-like PTLD, especially in cases with necrosis and high mitotic index, may resemble EBV-positive DLBCL, NOS. Unlike EBV-positive DLBCL, NOS, IM-like PTLD retains, at least in part, the tissue architecture, blasts are of both B-cell and T-cell lineages and B-cell clonality is negative.

RS-like cells are often seen in IM-like PTLD and in P-PTLD; therefore, cHL needs to be excluded, as mentioned above.

A graft reaction may show a polymorphic lymphoid infiltrate; the presence of numerous EBV positive cells favors P-PTLD diagnosis.

Similarly to the corresponding T-cell lymphomas occurring in non-transplanted patients, in M-PTLD of T-cell lineage, the aberrant expression of B-cell markers by neoplastic T-cells may erroneously lead to a diagnosis of M-PTLD of B-cell lineage; cases positive for CD30 and EBV may simulate cHL-PTLD.

Histological and immunophenotypic details of ENKTL nasal-type and polymorphic PTLD of the GIT are presented in Figure 1. 

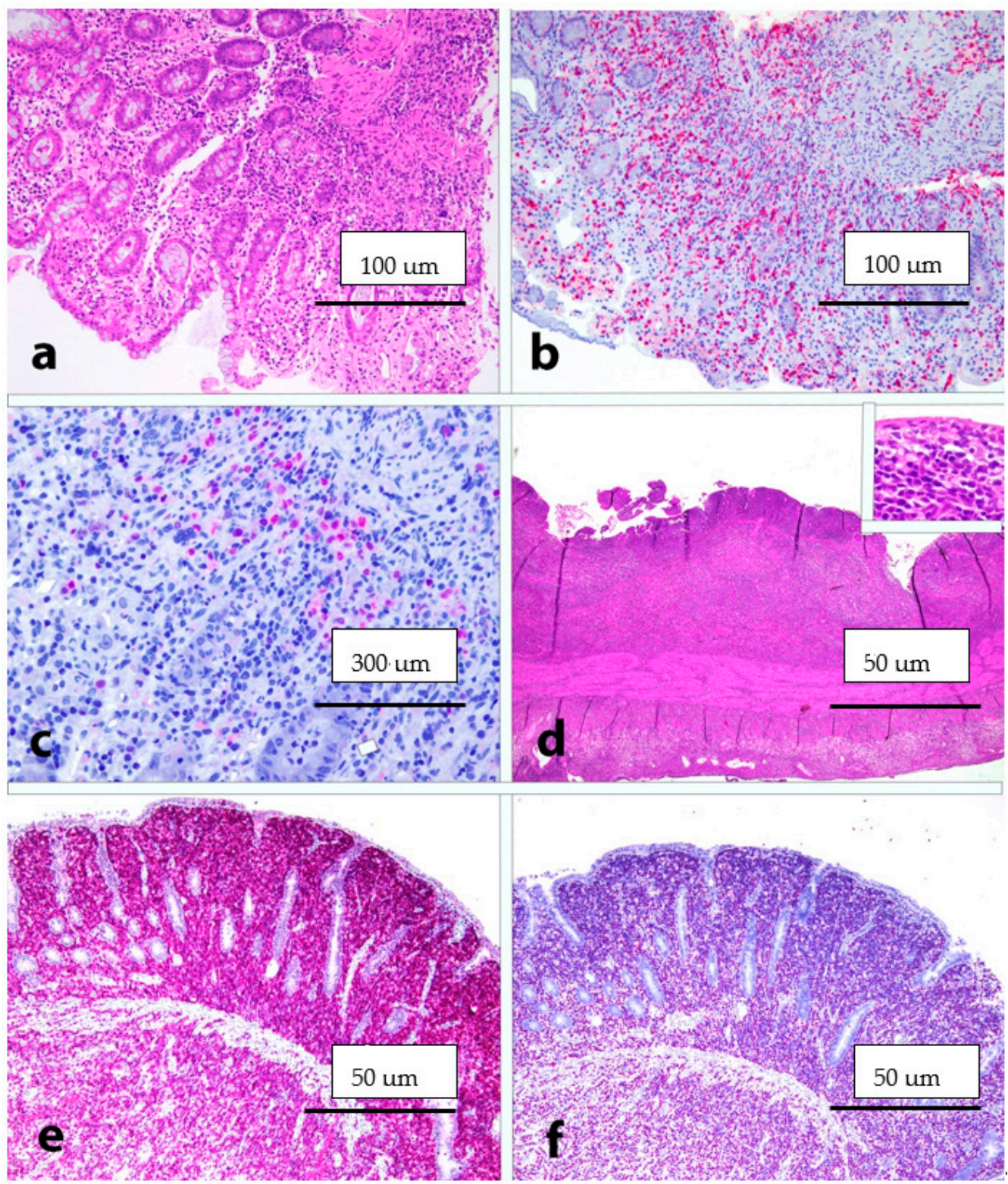

Figure 1. (a) PTLD: Medium power view showing a mucosal infiltrate with preserved tissue architecture (HE, $20 \times$ magnification); (b) PTLD: CD3 staining highlighting the mucosal infiltrate (immunohistochemical staining, 20×); (c) PTLD: EBER positivity (in situ hybridization; $40 \times$ magnification); (d) ENKTL, nasal-type: low power view showing the neoplastic infiltrate diffusely involving the intestinal wall; in the inset: details of neoplastic cells $(\mathrm{HE}, 10 \times$ magnification; inset, $40 \times$ magnification); (e) ENKTL, nasal-type: CD56 expression (immunohistochemical staining, 10× magnification); (f) ENKTL, nasal-type: EBER positivity (in situ hybridization; $10 \times$ magnification). All images are originals from Prof. S.A.P.

\subsection{Treatment and Outcome}

A reduction of immunosuppression (RI) represents the mainstay of PTLD treatment.

Non-destructive PTLDs usually regress with RI and the outcome is good, unless graft rejection develops [165].

P-PTLDs and a minority of M-PTLDs may regress with RI. The main concerns with RI are the risk of graft rejection and the time necessary for an initial response (approximately 3-5 weeks). EBV-positive PTLDs are more responsive to RI than EBV-negative cases [166].

Unresponsiveness to RI is more common in patients over 50 years, late-onset PTLD, bulky disease, multiorgan involvement, high lactate dehydrogenase and patients with an 
advanced stage of the disease $[151,166]$. In some P-PTLDs and most M-PDLDs of B-cell lineage not responding to RI, Rituximab treatment is sometimes indicated in association with CT $[167,168]$. Different chemotherapeutic schemes have been used in the treatment of M-PTLD, depending on the type of lymphoma, with CHOP being the most commonly used scheme [168]. Complete remission with combination CT is achieved in more than $90 \%$ of cases; unfortunately treatment-related toxicity remains high with an associated mortality of over 50\% [169]. Local therapies such as RT and surgery may be used in localized PTLDs, usually in combination with RI. T-cell immunotherapy represents another therapeutic strategy [170]. Unmanipulated donor lymphocytes represent a T-cell immunotherapy option as well as donor derived EBV-transformed lymphoblastoid cell line, and off-theshelf EBV-specific T cells [171-173].

\section{Conclusions}

EBV-driven LPDs represent a spectrum of entities with variable clinical behaviors. An accurate diagnosis begins from the awareness of this group of disorders by clinicians and pathologists and requires a combination of clinical, histological, immunophenotypic and molecular features. In GIT, the diagnosis can be even more complex as pathologists are often faced with small biopsy specimens. Additionally, EBV-associated T/NK-cell LPDs represent a particularly challenging diagnostic setting, owing to the discrepancy between the often aggressive clinical course and the subtle histological features which may be easily overlooked, leading to a misdiagnoses of these disorders as benign and inflammatory processes, ultimately resulting in improper treatments.

Author Contributions: Conceptualization, M.Z. (Magda Zanelli) and S.A.; methodology, A.P., F.S. and M.Z. (Magda Zanelli); formal analysis, A.C., C.C., F.M. (Francesco Merli), G.M., H.D.R. and L.C.; data curation, A.S., A.T., D.P., F.G., F.M. (Francesco Masia), I.T., L.D.M., M.F., M.M., M.Z. (Maurizio Zizzo), S.R. and V.F.; writing-original draft preparation, M.Z. (Magda Zanelli); writing-review and editing, M.Z. (Magda Zanelli); supervision, S.A.P. and S.A. All authors have read and agreed to the published version of the manuscript.

Funding: This research was funded by AIRC grant n. 21198.

Conflicts of Interest: The authors declare no conflict of interest.

\section{References}

1. Taylor, G.S.; Long, H.M.; Brooks, J.M.; Rickinson, A.B.; Hislop, A.D. The immunology of Epstein-Barr virus induced disease. Annu. Rev. Immunol. 2015, 33, 787-821. [CrossRef]

2. Young, L.S.; Yap, L.F.; Murray, P.G. Epstein-Barr virus: More than 50 years old and still providing surprises. Nat. Rev. Cancer 2016, 16, 789-802. [CrossRef]

3. Resk, S.A.; Weiss, L.M. Epstein-Barr virus-associated lymphoproliferative disorders. Hum. Pathol. 2007, 38, 1293-1304. [CrossRef]

4. Tanner, J.E.; Alfieri, C. The Epstein-Barr virus and post-transplant lymphoproliferative disease: Interplay of immunosuppression, EBV, and the immune system in disease pathogenesis. Transpl. Infect. Dis. 2001, 3, 60-69. [CrossRef]

5. Hakim, F.T.; Gress, R.E. Immunosenescence: Deficits in adaptative immunity in the elderly. Tissue Antigens 2007, 70, 179-189. [CrossRef] [PubMed]

6. Ghia, P.; Prato, G.; Stella, S.; Scielzo, C.; Geuna, M.; Caligaris-Cappio, F. Age-dependent accumulation of monoclonal CD4+ CD8+ double positive T lymphocytes in the peripheral blood of the elderly. Br. J. Haematol. 2007, 139, 780-790. [CrossRef] [PubMed]

7. Dolcetti, R.; Dal Col, J.; Martorelli, D.; Carbone, A.; Klein, E. Interplay among viral antigens, cellular pathways and tumor microenvironment in the pathogenesis of EBV-driven lymphoma. Semin. Cancer Biol. 2013, 13, 441-456. [CrossRef]

8. Swerdlow-SH, C.E.; Harris, N.L. WHO Classification of Tumours Haematopoietic and Lymphoid Tissues, Revised 4th ed.; WHO Classification of Tumours Editorial Board, Ed.; IARC: Lyon, France, 2017.

9. Dunmire, S.K.; Hogquist, K.A.; Balfour, H.H. Infectious mononucleosis. Curr. Top. Microbiol. 2015, 390, $151-209$.

10. Rickinson, A.B. Co-infections, inflammation and oncogenesis: Future directions for EBV research. In Seminars in Cancer Biology; Academic Press: Cambridge, MA, USA, 2014; pp. 99-115.

11. Price, A.M.; Luftig, M.A. To be or not IIb: A multi-step process for Epstein-Barr virus latency establishment and consequences for B cell tumorigenesis. PLoS Pathog. 2015, 11, e1004656. [CrossRef]

12. Dojcinov, S.D.; Fend, F.; Quintanilla-Martinez, L. EBV-positive lymphoproliferation of B-T- and NK-cell derivation in nonimmunocompromised hosts. Pathogens 2018, 7, 28. [CrossRef] 
13. Fujiwara, S.; Kimura, H. Editorial: Epstein-Barr virus-associated T/NK-cell lymphoproliferative diseases. Front. Pediatr. 2019 , 7, 285. [CrossRef]

14. Kim, W.Y.; Montes-Mojarro, I.A.; Fend, F.; Quintanilla-Martinez, L. Epstein-Barr virus-associated T and NK-cell lymphoproliferative diseases. Front. Pediatr. 2019, 7, 71. [CrossRef]

15. Kimura, H.; Fujiwara, S. Overview of EBV-associated T/NK-cell lymphoproliferative diseases. Front. Pediatr. $2019,6,417$. [CrossRef]

16. Dojcinov, S.D.; Venkataraman, G.; Raffeld, M.; Pittaluga, S.; Jaffe, E.S. EBV positive mucocutaneous ulcer. A study of 26 cases associated with various sources of immunosuppression. Am. J. Surg. Pathol. 2010, 34, 405-417. [CrossRef]

17. Ikeda, T.; Gion, Y.; Yoshino, T.; Sato, Y. A review of EBV-positive mucocutaneous ulcers focusing on clinical and pathological aspects. J. Clin. Exp. Hematopath. 2019, 59, 64-71. [CrossRef]

18. Ikeda, T.; Gion, Y.; Nishimura, M.F.; Yoshino, T.; Sato, Y. Epstein-Barr Virus-positive mucocutaneous ulcer: A unique and curious disease entity. Int. J. Mol. Sci. 2021, 22, 1053. [CrossRef]

19. Matnani, R.; Peker, D. Azathioprine induced Epstein Barr virus-positive mucocutaneous ulcer arising in perianal fistula and abscess associated with Crohn's disease. J. Crohn's Colitis 2014, 8, 1747-1748. [CrossRef] [PubMed]

20. Moran, N.R.; Webster, B.; Lee, K.M.; Trotman, J.; Kwan, Y.-L.; Napoli, J.; Leong, R.W. Epstein Barr virus-positive mucocutaneous ulcer of the colon associated Hodgkin lymphoma in Crohn's disease. World J. Gastroenterol. 2015, 21, 6072-6076. [CrossRef]

21. Juan, A.; Lobaton, T.; Tapja, G.; Manosa, M.; Cabrè, E. Epstein-Barr virus-positive mucocutaneous ulcer in Crohn's disease. A condition to consider in immunosuppressed IBD patients. Dig. Liver Dis. 2017, 49, 934-937. [CrossRef] [PubMed]

22. Zanelli, M.; Mengoli, M.C.; Valli, R.; Froio, E.; Bisagni, A.; Zizzo, M.; De Marco, L.; Ascani, S. Primary classic Hodgkin lymphoma of the ileum and Epstein-Barr virus mucocutaneous ulcer of the colon: Two entities compared. Virchows Archiv. 2019, 474, 117-123. [CrossRef] [PubMed]

23. Osman, M.; Al Salihi, M.; Abu Sitta, E.; Al Hadidi, S. A rare case of Epstein-Barr virus mucocutaneous ulcer of the colon. BMJ Case Rep. 2017, bcr2017220717. [CrossRef]

24. Zanelli, M.; Zizzo, M.; Foroni, M.; De Marco, L.; Martino, G.; Ascani, S. EBV-positive mucocutaneous ulcer within colonic diverticulitis mimicking diffuse large B-cell lymphoma. Ann. Hematol. 2019, 98, 1795-1797. [CrossRef] [PubMed]

25. Volaric, A.K.; Singh, K.; Gru, A.A. Rare EBV-associated B cell neoplasms of the gastrointestinal tract. Semin. Diagn. Pathol. 2021, 38, 38-45. [CrossRef]

26. Ikeda, T.; Gion, Y.; Sakamoto, M.; Tachibana, T.; Nishikori, A.; Nishimura, M.F.; Yoshino, T.; Sato, Y. Clinicopathological analysis of 34 Japanese patients with EBV-positive mucocutaneous ulcer. Mod. Pathol. 2020, 33, 2437-2448. [CrossRef] [PubMed]

27. Prieto-Torres, L.; Erana, I.; Gil-Redondo, R.; de la Riva, I.G.; Manso, R.; Pajares, R.; Cordoba, R.; Machan, S.; Ara, M.; Requena, L.; et al. The spectrum of EBV-positive mucocutaneous ulcer: A study of 9 cases. Am. J. Surg. Pathol. 2019, 43, 201-210. [CrossRef] [PubMed]

28. Goetgebuer, R.L.; van der Woude, C.J.; de Ridder, L.; Doukas, M.; de Vries, A.C. Clinical and endoscopic complications of Epstein-Barr virus in inflammatory bowel disease: An illustrative case series. Int. J. Colorectal. Dis. 2019, 34, 923-926. [CrossRef]

29. Pugh, M.R.; Leopold, G.D.; Morgan, M.; Christian, A.D.; Hewett, R.; Durai, D.; Wagstaff, J.; Harris, D.; Dojcinov, S.D. Epstein Barr virus-positive mucocutaneous ulcers complicate colitis caused by immune checkpoint regulator therapy and associate with colon perforation. Clin. Gastroenterol. Hepatol. 2020, 18, 1785. [CrossRef]

30. Daroontum, T.; Kohno, K.; Eladi, A.E.; Satou, A.; Sakakibara, A.; Matsukage, S.; Yakushiji, N.; Ya-In, C.; Nakamura, S.; Asano, N.; et al. Comparison of Epstein-Barr virus-positive mucocutaneous ulcer associated with treated lymphoma or methotrexate in Japan. Histopathology 2018, 72, 1115-1127. [CrossRef]

31. Morita, N.; Okuse, C.; Suetani, K.; Nakano, H.; Hiraishi, T.; Ishigooka, S.; Mori, S.; Shimamura, T.; Asakura, T.; Koike, J.; et al. A rare case of Epstein-Barr virus-positive mucocutaneous ulcer that developed into an intestinal obstruction: A case report. BMC Gastroenterol. 2020, 20, 9. [CrossRef]

32. Ishikawa, E.; Satou, A.; Nakamura, M.; Nakamura, S.; Fujishiro, M. Epstein-Barr virus positive B-cell lymphoproliferative disorders of the gastrointestinal tract. Cancers 2021, 13, 3815. [CrossRef]

33. Sinit, R.B.; Horan, K.L.; Dorer, R.K.; Aboulafia, D.M. Epstein-Barr virus-positive mucocutaneous ulcer: Case report and review of the first 100 published cases. Clin. Lymphoma Myeloma Leuk. 2019, 19, E81-E92. [CrossRef] [PubMed]

34. Miyagi, S.; Ishikawa, E.; Nakamura, M.; Shimada, K.; Yamamura, T.; Furukawa, K.; Tanaka, T.; Mabuchi, S.; Tsuyuki, Y.; Kohno, K.; et al. Reappraisal of primary Epstein-Barr virus (EBV)-positive diffuse large B-cell lymphoma of the gastrointestinal tract. Am. J. Surg. Pathol. 2020, 44, 1173-1183. [CrossRef] [PubMed]

35. Ishikawa, E.; Kato, S.; Shimada, K.; Tanaka, T.; Suzuki, Y.; Satou, A.; Kohno, K.; Sakakibara, A.; Yamamura, T.; Nakamura, M.; et al. Clinicopathological analysis of primary intestinal diffuse large B-cell lymphoma: Prognostic evaluation of CD5, PD-L1 and Epstein-Barr virus on tumor cells. Cancer Med. 2018, 7, 6051-6063. [CrossRef]

36. Castillo, J.J.; Beltran, B.E.; Miranda, R.N.; Young, K.H.; Chavez, J.C.; Sotomayor, E.M. EBV-positive large B-cell lymphoma, not otherwise specified: 2018 update on diagnosis, risk-stratification and management. Am. J. Hematol. 2018, 93, 953-962. [CrossRef]

37. Sanguedolce, F.; Zanelli, M.; Ascani, S.; Zizzo, M.; Tortorella, S.; Soriano, A.; Fiorelli, A.; Cocco, G.; Ardò, N.; Sollitto, F.; et al. PD-L1 as a prognostic and predictive biomarker in neuroendocrine tumors of the lung: State of the art and future perspectives. Minerva Respir. Med. 2021, 60, 36-51. [CrossRef] 
38. Hu, L.Y.; Xu, X.L.; Rao, H.L.; Chen, J.; Lai, R.C.; Huang, H.Q.; Jiang, W.Q.; Lin, T.Y.; Xia, Z.J.; Cai, Q.Q. Expression and clinical value of programmed cell death-ligand 1 (PD-L1) in diffuse large B-cell lymphoma: A retrospective study. Clin. J. Cancer 2017, 36, s40880. [CrossRef]

39. Georgiou, K.; Chen, L.; Berglund, M.; Ren, W.; de Miranda, N.; Lisboa, S.; Fangazio, M.; Zhu, S.D.; Hou, Y.; Wu, K.; et al. Genetic basis of PD-L1 overexpression in diffuse large B-cell lymphoma. Blood 2016, 127, 3026-3034. [CrossRef] [PubMed]

40. McCord, R.; Bolen, C.R.; Koeppen, H.; Kadel, E.E.; Oestergaard, M.Z.; Nielsen, T.; Sehn, L.H.; Venstrom, J.M. PD-L1 and tumor-associated macrophages in de novo DLBCL. Blood Adv. 2019, 3, 531-540. [CrossRef]

41. Kiyasu, J.; Miyoshi, H.; Hirata, A.; Arakawa, F.; Ichikawa, A.; Niino, D.; Sugita, Y.; Yufu, Y.; Choi, I.; Abe, Y.; et al. Expression of programmed cell death ligand 1 is associated with poor overall survival in patients with diffuse large B-cell lymphoma. Blood 2015, 126, 2193-2201. [CrossRef]

42. Ishikawa, E.; Nakamura, M.; Shimada, K.; Tanaka, T.; Satou, A.; Kohno, K.; Sakakibara, A.; Furukawa, K.; Yamamura, T.; Miyahara, R. Prognostic impact of PD-L1 expression in primary gastric and intestinal diffuse large B-cell lymphoma. J. Gastroenterol. 2020, 55, 39-50. [CrossRef]

43. Devaney, K.; Jaffe, E.S. The surgical pathology of gastrointestinal Hodgkin's disease. Am. J. Clin. Pathol. 1991, 95, 794-801. [CrossRef] [PubMed]

44. Ma, J.; Wang, Y.; Zhao, H.; Liu, S.; Li, Q.; Lin, L.; Yue, Y.; Wang, X.; Zhao, Z.; Yu, Y.; et al. Clinical characteristics of 26 patients with primary extranodal Hodgkin lymphoma. Int. J. Clin. Exp. Pathol. 2014, 7, 5045-5050.

45. Morgan, P.B.; Kessel, I.L.; Xiao, S.Y.; Colman, M. Uncommon presentations of Hodgkin's disease. Case 1. Hodgkin's disease of the jejunum. J. Clin. Oncol. 2004, 22, 193-195. [CrossRef] [PubMed]

46. Da Costa, A.; Flora, A.C.; Soares, F.A.; de Lima, V.C.C. Primary Hodgkin lymphoma of the rectum: An unusual presentation. J. Clin. Oncol. 2011, 29, 268-270. [CrossRef]

47. Sharma, S.; Rana, S.; Kapur, S.; Jairajpuri, Z.S. Primary intestinal Hodgkin lymphoma: An uncommon presentation. J. Lab. Physicians 2013, 5, 124-126. [PubMed]

48. Vaduvesan, J.A.; Nair, R.A.; Nambiar, K.R. Primary classical Hodgkin lymphoma of rectum: Report of an extremely rare case and review of the literature. Indian J. Pathol. Microbiol. 2017, 60, 412-414.

49. Parente, P.; Zanelli, M.; Zizzo, M.; Carosi, I.; Di Candia, L.; Sperandeo, M.; Lacedonia, D.; Fesce, V.F.; Ascani, S.; Graziano, P. Primary pulmonary Hodgkin lymphoma presenting as multiple cystic lung lesions: Diagnostic usefulness of cell block. Cytopathology 2020, 31, 236-239. [CrossRef] [PubMed]

50. Kumar, S.; Fend, F.; Quintanilla-Martinez, L.; Kingma, D.; Sorbara, L.; Raffeld, M.; Banks, P.M.; Jaffe, E.S. Epstein-Barr viruspositive primary gastrointestinal Hodgkin's disease: Association with inflammatory bowel disease and immunosuppression. Am. J. Surg. Pathol. 2000, 24, 66. [CrossRef] [PubMed]

51. Barzilai, M.; Polliack, A.; Avivi, I.; Herishanu, Y.; Ram, R.; Tang, C.; Perry, C.; Sarid, N. Hodgkin lymphoma of the gastrointestinal tract in patients with inflammatory bowel disease: Portrait of a rare entity. Leuk. Res. 2018, 71, 1-5. [CrossRef]

52. Gibson, B.; Bajramovic Podoli, M.; Baumgartner, E.M.; Haninger Maley, D. Syncitial variant of nodular sclerosis classical Hodgkin lymphoma of the terminal ileum in a patient with lonstanding Crohn's disease. Ann. Clin. Lab. Sci. 2016, 46, $219-221$.

53. Gualco, G.; Ortega, V.; Chioato, L.; Musto, M.L.; Bacchi, L.M.; Weiss, L.M.; Bacchi, C.E. Hodgkin's lymphoma presenting as dominant gastric lesion in immunocompetent patients: Report of 5 cases with EBV analysis. Int. J. Surg. Pathol. 2011, 19, 235-240. [CrossRef] [PubMed]

54. Parente, P.; Zanelli, M.; Sanguedolce, F.; Mastracci, L.; Graziano, P. Hodgkin Reed-Sternberg-like cells in non-Hodgkin lymphoma. Diagnostics 2020, 10, 1019. [CrossRef] [PubMed]

55. Ansell, S.M. Hodgkin lymphoma: A 2020 update on diagnosis, risk stratification and management. Am. J. Haematol. 2020, 95, 978-989. [CrossRef] [PubMed]

56. Delecleuse, H.J.; Anagnostopoulos, I.; Dallenbach, F.; Hummel, M.; Marafioti, T.; Schneider, U.; Huhn, D.; Schmidt-Westhausen, A.; Reichart, P.A.; Gross, U.; et al. Plasmablastic lymphomas of the oral cavity: A new entity associated with the human immunodeficiency virus infection. Blood 1997, 89, 1413-1420. [CrossRef]

57. Zizzo, M.; Zanelli, M.; Martiniani, R.; Sanguedolce, F.; De Marco, L.; Martino, G.; Parente, P.; Annessi, V.; Manzini, L.; Ascani, S. Oral plasmablastic lymphoma: A case report. Medicine 2020, 99, e22335. [CrossRef]

58. Morscio, J.; Dierickx, D.; Nijs, J.; Verhoef, G.; Bittoun, E.; Vanoeteren, X.; Wlodarska, I.; Sagaert, X.; Tousseyn, T. Clinicopathologic comparison of plasmablastic lymphoma in HIV-positive, immunocompetent and posttransplant patients single-center series of 25 cases and meta-analysis of 277 reported cases. Am. J. Surg. Pathol. 2014, 38, 875-886. [CrossRef]

59. Castillo, J.J.; Bibas, M.; Miranda, R.N. The biology and treatment of plasmablastic lymphoma. Blood 2015, 125, 2323-2330. [CrossRef]

60. Harmon, C.M.; Smith, L.B. Plasmablastic lymphoma a review of clinicopathologic features and differential diagnosis. Arch. Pathol. Lab. Med. 2016, 140, 1074-1078. [CrossRef]

61. Sanguedolce, F.; Zanelli, M.; Zizzo, M.; Martino, G.; Rossi, C.; Parente, P.; Ascani, S. Clinical, pathological and molecular features of plasmablastic lymphoma arising in the gastrointestinal tract: A review and reappraisal. Pathol. Res. Pract. 2020, $216,152973$. [CrossRef]

62. Lopez, A.; Abrisqueta, P. Plasmablastic lymphoma: Current perspectives. Blood Lymph. Cancer Targets Ther. 2018, 8, 63-70. [CrossRef] 
63. Luria, L.; Nguyen, J.; Zhou, J.; Jaglal, M.; Sokol, L.; Messina, J.L.; Coppola, D.; Zhang, L. Manifestations of gastrointestinal plasmablastic lymphoma: A case series with literature review. World J. Gastroenterol. 2014, 20, 11894-11903. [CrossRef]

64. Liu, C.; Varikatt, W.; Ping, C.H. Plasmablastic lymphoma presenting as a colonic stricture in Crohn's disease. Pathology 2014, 46, 77-78. [CrossRef]

65. Zanelli, M.; Ragazzi, M.; Valli, R.; De Marco, L.; Cecinato, P.; Azzolini, F.; Ferrari, A.; Bacci, F.; Ascani, S. Unique presentation of a plasmablastic lymphoma superficially involving the entire large bowel. Pathol. Res. Pract. 2015, 211, 1030-1033. [CrossRef]

66. Valera, A.; Balague, O.; Colomo, L.; Martinez, A.; Delabie, J.; Taddesse-Heath, L.; Jaffe, E.S.; Campo, E. IG/MYC rearrangements are the main cytogenetic alteration in plasmablastic lymphomas. Am. J. Surg. Pathol. 2010, 34, 1686-1694. [CrossRef]

67. Montes-Moreno, S.; Martinez-Magunacelaya, N.; Zecchini-Barrese, T.; Gonzalez de Villambrosia, S.; Linares, E.; Ranchal, T.; Rodriguez-Pinilla, M.; Battle, A.; Cereceda-Company, L.; Revert-Arce, J.B.; et al. Plasmablastic lymphoma phenotype is determined by genetic alterations in MYC and PRDM1. Mod. Pathol. 2017, 30, 85-94. [CrossRef] [PubMed]

68. Castillo, J.J. Plasmablastic lymphoma: Are more intensive regimens needed? Leuk. Res. 2011, 35, 1547-1548. [CrossRef] [PubMed]

69. Pretscher, D.; Kalish, A.; Wilhelm, M.; Birkmann, J. Refractory plasmablastic lymphoma. A review of treatment options beyond standard therapy. Ann. Hematol. 2017, 96, 967-970. [CrossRef]

70. Castillo, J.J.; Reagan, J.L.; Sikov, W.M.; Winer, E.S. Bortezomib in combination with infusional dose-adjusted EPOCH for the treatment of plasmablastic lymphoma. Br. J. Haematol. 2015, 169, 352-355. [CrossRef]

71. Al-Malki, M.M.; Castillo, J.J.; Sloan, J.M.; Re, A. Hematopoietic cell transplantation for plasmablastic lymphoma: A review. Biol. Blood Marrow Transplant. 2014, 20, 1877-1884. [CrossRef] [PubMed]

72. Chen, B.J.; Chuang, S.S. Lymphoid neoplasms with plasmablastic differentiation: A comprehensive review and diagnostic approaches. Adv. Anat. Pathol. 2020, 27, 61-74. [CrossRef] [PubMed]

73. Loghavi, S.; Alayed, K.; Aladily, T.N.; Zuo, Z.; Ng, S.B.; Tang, G.; Hu, S.; Yin, C.C.; Miranda, R.N.; Medeiros, L.J.; et al. Stage, age and EBV status impact outcomes of plasmablastic lymphoma patients: A clinicopathologic analysis of 61 patients. J. Hematol. Oncol. 2015, 8, 65. [CrossRef] [PubMed]

74. Laurent, C.; Fabiani, B.; Do, C.; Tchernonog, E.; Cartron, G.; Gravelle, P.; Amara, N.; Malot, S.; Palisoc, M.M.; Copie-Bergman, C.; et al. Immune-checkpoint expression in Epstein-Barr virus positive and negative plasmablastic lymphoma: A clinical and pathological study in 82 patients. Haematologica 2016, 101, 976-984. [CrossRef]

75. Zanelli, M.; Sanguedolce, F.; Zizzo, M.; Palicelli, A.; Bassi, M.C.; Santandrea, G.; Martino, G.; Soriano, A.; Caprera, C.; Corsi, M.; et al. Primary effusion lymphoma occurring in the setting of transplanted patients: A systematic review of a rare, life-threatening post-transplantation occurrence. BMC Cancer 2021, 21, 468. [CrossRef]

76. Chadburn, A.; Hyjek, E.; Mathew, S.; Cesarman, E.; Said, J.; Knowles, D.M. KSHV-positive solid lymphomas represent an extra-cavitary variant of primary effusion lymphoma. Am. J. Surg. Pathol. 2004, 28, 1401-1416. [CrossRef]

77. Kim, Y.; Leventaki, V.; Bhaijee, F.; Jackson, C.C.; Medeiros, L.J.; Vega, F. Extracavitary/solid variant of primary effusion lymphoma. Ann. Diagn. Pathol. 2012, 16, 441-446. [CrossRef]

78. Pan, Z.G.; Zhang, Q.Y.; Lu, Z.B.L.; Quinto, T.; Rozenvald, I.B.; Liu, L.T.; Wilson, D.; Reddy, V.; Huang, Q.; Wang, H.Y.; et al. Extracavitary KSHV-associated large B-cell lymphoma: A distinct entity or a subtype of primary effusion lymphoma? Study of 9 cases and review of an additional 43 cases. Am. J. Surg. Pathol. 2012, 36, 1129-1140. [CrossRef] [PubMed]

79. Costes, V.; Faumont, N.; Cesarman, E.; Rousset, T.; Meggetto, F.; Delsol, G.; Brousset, P. Human herpes-virus-8-associated lymphoma of the bowel in human immunodeficiency virus-positive patients without history of primary effusion lymphoma. Hum. Pathol. 2002, 33, 846-849. [CrossRef]

80. Navarro, J.T.; Ribera, J.M.; Juncà, J.; Millà, F. Anorectal lymphoma without effusion associated with human herpesvirus-8 and type 1 Epstein-Barr virus in an HIV infected patient. Hum. Pathol. 2003, 34, 630. [CrossRef]

81. Liao, G.; Cai, J.; Yue, C.; Quing, X. Extracavitary/solid variant of primary effusion lymphoma presenting as a gastric mass. Exp. Mol. Pathol. 2015, 99, 445-448. [CrossRef] [PubMed]

82. Pantanowitz, L.; Wu, Z.; Dezube, B.J.; Pihan, G. Extracavitary primary effusion lymphoma of the anorectum. Clin. Lymphoma Myeloma 2005, 6, 149-152. [CrossRef]

83. Zanelli, M.; Bertuzzi, C.; Zizzo, M.; Martino, G.; Sabattini, E.; Ascani, S. Extracavitary primary effusion lymphoma in a post-transplantation patient. Br. J. Hematol. 2019, 187, 55. [CrossRef]

84. DePond, W.; Said, J.W.; Tasaka, T.; de Vos, S.; Kahn, D.; Cesarman, E.; Knowles, D.M.; Koeffler, H.P. Kaposi's sarcoma-associated herpesvirus and human herpesvirus 8 (KSHV/HHV8)-associated lymphoma of the bowel. Report of two cases in HIV-positive men with secondary effusion lymphomas. Am. J. Surg. Pathol. 1997, 21, 719-724. [CrossRef] [PubMed]

85. Huang, Q.; Chang, K.L.; Gaal, K.; Aber, D.A. Primary effusion lymphoma with subsequent development of a small bowel mass in an HIV-seropositive patient: A case report and literature review. Am. J. Surg. Pathol. 2002, 26, 1363-1367. [CrossRef] [PubMed]

86. Oster, C.; Stein, T.; Kitahara, S.; Alkan, S.; Huang, Q. Kaposi sarcoma-associated herpesvirus/human herpesvirus 8-associated extracavitary primary effusion lymphoma presenting as multiple lymphomatous polyposis. Hum. Pathol. 2018, 79, 177-183. [CrossRef]

87. Pellet Madan, R.; Hand, J. Human herpesvirus 6, 7, and 8 in solid organ transplantation: Guidelines from the American Society of Transplantation Infectious Diseases Community of Practice. Clinical. Transplant. 2019, 33, e13518. [CrossRef] [PubMed]

88. Zanelli, M.; Zizzo, M.; Bisagni, A.; Froio, E.; De Marco, L.; Valli, R.; Filosa, A.; Luminari, S.; Martino, G.; Massaro, F.; et al. Germinotropic lymphoproliferative disorder: A systematic review. Ann. Hematol. 2020, 99, 2243-2253. [CrossRef] 
89. Zanelli, M.; Fraternali Orcioni, G.; Zizzo, M.; De Marco, L.; Martino, G.; Cerrone, G.; Cabra, A.D.; Ascani, S. HHV-8- and EBV-positive germinotropic lymphoproliferative disorder. Ann. Hematol. 2019, 98, 2439-2441. [CrossRef]

90. Zanelli, M.; Stingeni, L.; Zizzo, M.; Martino, G.; Sanguedolce, F.; Marra, A.; Crescenzi, B.; Pileri, S.A. HHV8-positive Castleman disease and in situ mantle cell neoplasia within dermatopathic lymphadenitis, in longstanding psoriasis. Diagnostics 2021, 11, 1150. [CrossRef]

91. Lurain, K.; Polizzotto, M.N.; Aleman, K.; Bhutani, M.; Wyvill, K.M.; Goncalves, P.H.; Ramaswami, R.; Marshall, V.A.; Miley, W.; Steinberg, S.M.; et al. Viral, immunologic and clinical features of primary effusion lymphoma. Blood 2019, 133, $1753-1761$. [CrossRef]

92. Okada, S.; Goto, H.; Yotsumoto, M. Current status of treatment for primary effusion lymphoma. Intractable Rare Dis. Res. 2014, 3, 65-74. [CrossRef]

93. Burkitt, D. A sarcoma involving the jaw of African children. Br. J. Surg. 1958, 46, 218-223. [CrossRef] [PubMed]

94. Epstein, M.A.; Achong, B.G.; Barr, Y.M. Virus particle in cultured lymphoblasts from Burkitt's lymphoma. Lancet 1964, 1, 702-703. [CrossRef]

95. De Thé, G.; Geser, A.; Day, N.E.; Tukei, P.M.; Williams, E.H.; Beri, D.P.; Smith, P.G.; Dean, A.G.; Bronkamm, G.W.; Feorino, P.; et al. Epidemiological evidence for causal relationship between Epstein-Barr virus and Burkitt's lymphoma from Ugandan prospective study. Nature 1978, 274, 756-761. [CrossRef]

96. Van Den Bosch, C. A role for RNA viruses in the pathogenesis of Burkitt's lymphoma: The need for reappraisal. Adv. Hematol. 2012, 2012, 494758. [CrossRef] [PubMed]

97. Abate, F.; Ambrosio, M.R.; Mundo, L.; Laginestra, M.A.; Fulingni, F.; Rossi, M.; Zairis, S.; Gazaneo, S.; De Falco, G.; Lazzi, S.; et al. Distinct viral and mutational spectrum of endemic Burkitt lymphoma. PLoS Pathog. 2015, 11, e1005158. [CrossRef]

98. De Thè, G. Is Burkitt's lymphoma related to perinatal infection by Epstein-Barr virus? Lancet 1977, 309, 335-338. [CrossRef]

99. Satou, A.; Asano, N.; Nakazawa, A.; Osumi, T.; Tsurusawa, M.; Ishiguro, A.; Elsayed, A.A.; Nakamura, N.; Ohshima, K.; Kinoshita, T.; et al. Epstein-Barr virus (EBV)-positive sporadic Burkitt lymphoma: And age-related lymphoproliferative disorder? Am. J. Surg. Pathol. 2015, 39, 227-235. [CrossRef] [PubMed]

100. Mbulaiteye, S.M.; Anderson, W.F.; Ferlay, J.; Bhatia, K.; Chang, C.; Rosenberg, P.S.; Devesa, S.S.; Parkin, D.M. Pediatric, elderly and emerging adult-onset peaks in Burkitt's lymphoma incidence diagnosed in four continents, excluding Africa. Am. J. Hematol. 2012, 87, 573-578. [CrossRef]

101. Gibson, T.M.; Morton, L.M.; Shiels, M.S.; Clarke, C.A.; Engels, E.A. Risk of non-Hodgkin lymphoma subtypes in HIV-infected people during the HAART era: A population-based study. AIDS 2014, 28, 2313-2318. [CrossRef]

102. Molyneux, E.M.; Rochford, R.; Griffin, B.; Newton, R.; Jackson, G.; Menon, G.; Harrison, C.J.; Israels, T.; Bailey, S. Burkitt's lymphoma. Lancet 2012, 379, 1234-1244. [CrossRef]

103. England, R.J.; Oillay, K.; Davidson, A.; Numanoglu, A.; Millar, A.J. Intussusception as a presenting feature of Burkitt lymphoma: Implications for management and outcome. Pediatr. Surg. Int. 2012, 28, 267-270. [CrossRef] [PubMed]

104. Rowe, M.; Kelly, G.L.; Bell, A.I.; Rickinson, A.B. Burkitt's lymphoma: The Rosetta stone deciphering Epstein-Barr virus biology. Sem. Cancer Biol. 2009, 19, 377-388. [CrossRef]

105. Allday, M.J. How does Epstein-Barr virus (EBV) complement the activation of MYC in the pathogenesis of Burkitt's lymphoma? Semin. Cancer Biol. 2009, 19, 366-376. [CrossRef]

106. Duleavy, K.; Little, R.F.; Wilson, W.H. Update on Burkitt lymphoma. Hematol. Oncol. Clin. N. Am. 2016, 30, 1333-1343. [CrossRef]

107. Zanelli, M.; Sanguedolce, F.; Palicelli, A.; Zizzo, M.; Martino, G.; Caprera, C.; Fragliasso, V.; Soriano, A.; Valle, L.; Ricci, S.; et al. EBV-driven lymphoproliferative disorders and lymphomas of the gastrointestinal tract: A spectrum of entities with a common denominator (Part 1). Cancers 2021, 13, 4578. [CrossRef]

108. Zanelli, M.; Sanguedolce, F.; Palicelli, A.; Zizzo, M.; Martino, G.; Caprera, C.; Fragliasso, V.; Soriano, A.; Valle, L.; Ricci, S.; et al. EBV-driven lymphoproliferative disorders and lymphomas of the gastrointestinal tract: A spectrum of entities with a common denominator (Part 2). Cancers 2021, 13, 4527. [CrossRef]

109. Straus, S.E. The chronic mononucleosis syndrome. J. Infect. Dis. 1988, 157, 405-412. [CrossRef]

110. Jones, J.; Shurin, S.; Abramowsky, C.; Tubbs, R.R.; Sciotto, C.G.; Wahl, R.; Sands, J.; Gottman, D.; Katz, B.Z.; Sklar, J. T-cell lymphomas containing Epstein-Barr viral DNA in patients with chronic Epstein-Barr virus infections. N. Engl. J. Med. 1988, 318, 733-741. [CrossRef]

111. Okano, M.; Kawa, K.; Kimura, H.; Yachie, A.; Wakiguchi, H.; Maeda, A.; Imai, S.; Ohga, S.; Kanegane, H.; Tsuchiya, S.; et al. Proposed guidelines for diagnosing chronic active Epstein-Barr virus infection. Am. J. Hematol. 2005, 80, 64-69. [CrossRef]

112. Cohen, J.I.; Jaffe, E.S.; Dale, J.K.; Pittaluga, S.; Heslop, H.E.; Rooney, C.M.; Gottschalk, S.; Bollard, C.M.; Rao, V.K.; Marques, A.; et al. Characterization and treatment of chronic active Epstein-Barr virus disease: A 28-year experience in the United States. Blood 2011, 117, 5835-5849. [CrossRef]

113. Arai, A.; Imadome, K.; Watanabe, Y.; Yoshimori, M.; Koyama, T.; Kawaguchi, T.; Nakaseko, C.; Fujiwara, S.; Miura, O. Clinical features of adult-onset chronic active Epstein-Barr virus infection: A retrospective analysis. Int. J. Hematol. 2011, 93, 602-609. [CrossRef] [PubMed]

114. Kimura, H.; Hoshino, Y.; Hara, S.; Sugaya, N.; Kawada, J.; Shibata, Y.; Kojima, S.; Nagasaka, T.; Kuzushima, K.; Morishima, T. Differences between T-cell type and natural killer cell-type chronic active Epstein-Barr virus infection. J. Infect. Dis. 2005, 191, 531-539. [CrossRef] [PubMed] 
115. Kimura, H.; Morishima, T.; Kanegane, H.; Ohga, S.; Hoshino, Y.; Maeda, A.; Imai, S.; Okano, M.; Morio, T.; Yokota, S.; et al. Prognostic factors for chronic active Epstein-Barr virus infection. J. Infect. Dis. 2003, 187, 527-533. [CrossRef] [PubMed]

116. Isobe, Y.; Aritaka, N.; Setoguchi, Y.; Ito, K.; Kimura, H.; Hamano, Y.; Sugimoto, K.; Komatsu, N. T/NK cell type chronic active Epstein-Barr virus disease in adults: An underlying condition for Epstein-Barr virus-associated T/NK-cell lymphoma. J. Clin. Pathol. 2012, 65, 278-282. [CrossRef] [PubMed]

117. Roth, D.E.; Jones, A.; Smith, L.; Lai, R.; Preiksaitis, J.; Robinson, J. Severe chronic active Epstein-Barr virus infection mimicking steroid-dependent inflammatory bowel disease. Pediatr. Infect. Dis. J. 2005, 24, 261-264. [CrossRef]

118. Liu, R.; Wang, M.; Zhang, L.; Zhou, W.; Huang, Y.; Guo, H.; Gu, Y.; Chen, Y.; Li, Y.; Chen, C.; et al. The clinicopathologic features of chronic active Epstein-Barr virus infective enteritis. Mod. Pathol. 2019, 32, 387-395. [CrossRef]

119. Xu, W.; Jiang, X.; Chen, J.; Mao, Q.; Zhao, X.; Sun, X.; Zhong, L.; Rong, L. Chronic active Epstein-Barr virus infection involving gastrointestinal tract mimicking inflammatory bowel disease. BMC Gastroenterol. 2020, 20, 257. [CrossRef] [PubMed]

120. Tian, S.; Westbrook, L.M.; Xiao, S.Y.; Zhang, Y.; Huang, Y.; Wang, H.L. The morphologic features of primary Epstein-Barr virus infection in the gastrointestinal tract. An approach to correct diagnosis. Am. J. Surg. Pathol. 2019, 43, 1253-1263. [CrossRef]

121. Kimura, H.; Ito, Y.; Kawabe, S.; Gotoh, K.; Takahashi, Y.; Kojima, S.; Naoe, T.; Esaki, S.; Kikuta, A.; Sawada, A.; et al. EBVassociated T/NK-cell lymphoproliferative diseases in nonimmunocompromised hosts: Prospective analysis of 108 cases. Blood 2012, 119, 673-686. [CrossRef] [PubMed]

122. Ohshima, K.; Kimura, H.; Yoshino, T.; Kim, C.W.; Ko, H.Y.; Lee, S.S.; Peh, S.C.; Chan, J.K.C. Proposed categorization of pathological states of EBV-associated T/natural killer-cell lymphoproliferative disorder (LPD) in children and young adults: Overlap chronic active EBV infection and infantile fulminant EBV T-LPD. Pathol. Int. 2008, 58, 209-217. [CrossRef]

123. Kawa, K.; Sawada, A.; Sato, M.; Okamura, T.; Sakata, N.; Kondo, O.; Kimoto, T.; Yamada, K.; Tokimasa, S.; Yasui, M.; et al. Excellent outcome of allogenic hematopoietic SCT with reduced-intensity conditioning for the treatment of chronic active EBV infection. Bone Marrow Transplant. 2011, 46, 77-83. [CrossRef] [PubMed]

124. Arai, A. Advances in the study of chronic active Epstein-Barr virus infection: Clinical features under the 2016 WHO classification and mechanisms of development. Front. Pediatr. 2019, 7, 14. [CrossRef]

125. Fujiwara, S.; Nakamura, H. Chronic active Epstein-Barr virus infection: Is it immunodeficiency, malignancy or both? Cancers 2020, 12, 3202. [CrossRef]

126. Sanchez-Romero, C.; Bogna-Molina, R.; Paes de Almeda, O.; Santos-Silva, A.; Prado-Ribeiro, A.C.; Brandao, T.B.; Carlos, R. Extranodal NK/T cell lymphoma, nasal type: An updated overview. Crit. Rev. Oncol. Hematol. 2021, 159, 103237. [CrossRef] [PubMed]

127. Huang, Y.; De Leval, L.; Gaulard, P. Molecular underpinning of extranodal NK-T-cell lymphoma. Best. Pract. Res. Clin. Haematol. 2013, 26, 57-74. [CrossRef]

128. Takada, H.; Imadome, K.I.; Shibayama, H.; Yoshimori, M.; Wang, L.; Saitoh, Y.; Uota, S.; Yamaoka, S.; Koyama, T.; Shimizu, N.; et al. EBV induces persistent NF-kB activation and contributes to survival of EBV-positive neoplastic T-or NK-cells. PLoS ONE 2017, 12, e0174136.

129. Huang, Y.; De Reynies, A.; De Leval, L.; Ghazi, B.; Martin-Garcia, N.; Travert, M.; Bosq, J.; Briere, J.; Petit, B.; Thomas, E.; et al. Gene expression profiling identified emerging oncogenic pathways operating in extranodal NK/T-cell lymphoma, nasal type. Blood 2010, 115, 1226-1237. [CrossRef]

130. Lee, S.; Park, H.Y.; Kang, S.Y.; Kim, S.J.; Hwang, J.; Lee, S.; Kwak, S.H.; Park, K.S.; Yoo, H.Y.; Kim, W.S.; et al. Genetic alterations of JAK/STAT cascade and histone modification in extranodal NK/T-cell lymphoma nasal type. Oncotarget 2015, 6, 17764-17776. [CrossRef]

131. Jiang, L.; Gu, Z.H.; Yan, Z.Y.; Zhao, X.; Xie, Y.Y.; Zhang, Z.G.; Pan, C.M.; Hu, Y.; Cai, C.P.; Dong, Y.; et al. Exome sequencing identifies somatic mutations of DDX3X in natural killer/T-cell lymphoma. Nat. Genet. 2015, 47, 1061-1066. [CrossRef] [PubMed]

132. Takata, K.; Hong, M.E.; Sitthinamsuwan, P.; Loong, F.; Tan, S.Y.; Liau, J.Y.; Hsieh, P.P.; Ng, S.B.; Yang, S.F.; Pongpruttipan, T.; et al. Primary cutaneous NK/T-cell lymphoma, nasal type and CD56-positive peripheral T-cell lymphoma: A cellular lineage and clinicopathologic study of 60 patients from Asia. Am. J. Surg. Pathol. 2015, 39, 1-12. [CrossRef]

133. Chim, C.S.; Au, W.Y.; Shek, T.W.; Ho, Y.; Choy, C.; Ma, S.K.; Tung, H.M.; Liang, R.; Kwong, Y.L. CD56 positive lymphomas of the gastrointestinal tract. Cancer 2001, 91, 525-533. [CrossRef]

134. Kim, S.J.; Jung, H.A.; Chuang, S.S.; Hong, H.; Guo, C.C.; Cao, J.; Hong, X.N.; Suzuki, R.; Kang, H.J.; Won, J.H.; et al. Extranodal natural killer/T-cell lymphoma involving the gastrointestinal tract: Analysis of clinical features and outcomes from the Asia Lymphoma Study Group. J. Hematol. Oncol. 2013, 16, 86. [CrossRef]

135. Hue, S.S.-S.; Oon, M.L.; Wang, S.; Tan, S.Y.; Ng, S.B. Epstein-Barr virus associated T-and NK-cell lymphoproliferative diseases: An update and diagnostic approach. Pathology 2020, 52, 111-127. [CrossRef] [PubMed]

136. Chim, C.S.; Ma, E.S.; Loong, F.; Kwong, Y.L. Diagnostic clues for natural killer lymphoma: Primary nodal presentation and the role of in situ hybridization for Epstein-Barr virus encoded early small RNA in detecting occult bone marrow involvement. J. Clin. Pathol. 2005, 58, 443-445. [CrossRef]

137. Yu, B.H.; Shui, R.H.; Sheng, W.Q.; Wang, C.F.; Lu, H.F.; Zhou, X.Y.; Zhu, X.Z.; Li, X.Q. Primary intestinal extranodal natural killer/T-cell lymphoma, nasal type: A comprehensive clinicopathological analysis of 55 cases. PLoS ONE 2016, 11, e0161831. [CrossRef] 
138. Susan, S.H.; Ng, S.B.; Wang, S.; Tan, S.Y. Diagnostic approach to T- and NK-cell lymphoproliferative disorders in the gastrointestinal tract. Semin. Diagn. Pathol. 2021, 38, 21-30. [CrossRef] [PubMed]

139. Xiong, J.; Zhao, W.L. Advances in multiple omics of natural-killer/T-cell lymphoma. J. Hematol. Oncol. 2018, 11, 134. [CrossRef]

140. McKelvie, P.A.; Climent, F.; Krings, G.; Hasserjian, R.P.; Abramson, J.S.; Pilch, B.Z.; Lee Harris, N.; Ferry, J.A.; Zukenberg, L.R.; Sohani, A.R. Small-cell predominant extranodal NK/T cell lymphoma, nasal type: Clinicopathological analysis of a series of cases diagnosed in a western population. Histopathology 2016, 69, 667-679. [CrossRef]

141. Zanelli, M.; Ragazzi, M.; Fiorino, S.; Foroni, M.; Cecinato, P.; Del Mar Jordana Sanchez, M.; Ascani, S.; De Marco, L. An italian case of intestinal anisakiasis with a presurgical diagnosis: Could this parasite represent an emerging disease? Pathol. Res. Pract. 2017, 213, 558-564. [CrossRef]

142. Melani, C.; Jaffe, E.S.; Wilson, W.H. Pathobiology and treatment of lymphomatoid granulomatosis, a rare EBV-driven disorder. Blood 2020, 135, 1344-1352. [CrossRef]

143. Sanguedolce, F.; Zanelli, M.; Zizzo, M.; Bisagni, A.; Soriano, A.; Cocco, G.; Palicelli, A.; Santandrea, G.; Caprera, C.; Corsi, M.; et al. Primary pulmonary B-cell lymphoma: A review and update. Cancers 2021, 13, 415. [CrossRef]

144. Van Vliet, C.; Spagnolo, D.V. T- and NK-cell lymphoproliferative disorders of the gastrointestinal tract: Review and update. Pathology 2020, 52, 128-141. [CrossRef] [PubMed]

145. Sanguedolce, F.; Zanelli, M.; Zizzo, M.; Luminari, S.; Martino, G.; Soriano, A.; Ricci, L.; Caprera, C.; Ascani, S. Indolent T-cell lymphoproliferative disorders of gastrointestinal tract (iTLPD-GI): A review. Cancers 2021, 13, 2790. [CrossRef]

146. Kwong, Y.-L.; Chan, T.S.Y.; Tan, D.; Kim, S.J.; Poon, L.-M.; Mow, B.; Khong, P.-L.; Loong, F.; Au-Yeung, R.; Iqbal, J.; et al. PD1 blockade with pembrolizumab is highly effective in relapsed or refractory NK/T-cell lymphoma failing l-asparaginase. Blood 2017, 129, 2437-2442. [CrossRef]

147. Hari, P.; Raj, R.V.; Olteanu, H. Targeting CD38 in refractory extranodal natural killer cell-T-cell lymphoma. N. Engl. J. Med. 2016, 375, 1501-1502. [CrossRef] [PubMed]

148. De Mel, S.; Hue, S.S.S.; Jeyasekharan, A.D.; Chng, W.J.; Ng, S.B. Molecular pathogenetic pathways in extranodal NK/T cell lymphoma. J. Hematol. Oncol. 2019, 12, 33. [CrossRef]

149. Gupta, D.; Mendonca, S.; Chakraborty, S.; Chatterjee, T. Post-transplant lymphoproliferative disorder. Indian J. Hemato. Blood Transfus. 2020, 36, 229-237. [CrossRef] [PubMed]

150. Al-Mansour, Z.; Nelson, B.P.; Evens, A.M. Post-transplant lymphoproliferative disease (PTLD): Risk factors, diagnosis and current treatment strategies. Curr. Hematol. Malig. Rep. 2013, 8, 173-183. [CrossRef]

151. Abbas, F.; El Kossi, M.; Shaheen, I.S.; Sharma, A.; Halawa, A. Post-transplantation lymphoproliferative disorders: Current concepts and future therapeutic approaches. World J. Transplant. 2020, 10, 29-46. [CrossRef] [PubMed]

152. Parker, A.; Bowles, K.; Bradley, A.; Emery, V.; Featherstone, C.; Gupte, G.; Marcus, R.; Parameshwar, J.; Ramsay, A.; Newstead, C. Diagnosis of post-transplant lymphoproliferative disorder in solid organ transplant recipients-BCSH and BTS Guidelines. Br. J. Haematol. 2010, 149, 675-692. [CrossRef] [PubMed]

153. Dolcetti, R. B lymphocytes and Epstein-Barr virus: The lesson of post-transplant lymphoproliferative disorders. Autoimmun. Rev. 2007, 7, 96-101. [CrossRef]

154. Fujimoto, A.; Suzuki, R. Epstein-Barr virus-associated post-transplant lymphoproliferative disorders after hematopoietic stem cell transplantation: Pathogenesis, risk factors and clinical outcomes. Cancers 2020, 12, 328. [CrossRef] [PubMed]

155. Nelson, B.P.; Nalesnik, M.A.; Bahler, D.W.; Locker, J.; Fung, J.J.; Swerdlow, S.H. Epstein-Barr virus-negative post-transplant lymphoproliferative disorders: A distinct entity? Am. J. Surg. Pathol. 2000, 24, 375-385. [CrossRef]

156. Ferla, V.; Rossi, F.G.; Goldaniga, M.C.; Baldini, L. Biological difference between Epstein-Barr virus positive and negative post-transplant lymphoproliferative disorders and their clinical impact. Front. Oncol. 2020, 10, 506. [CrossRef] [PubMed]

157. Menter, T.; Juskevicius, D.; Alikian, M.; Steiger, J.; Dirnhofer, S.; Tzankov, A.; Naresh, K.N. Mutational landscape of B-cell post-transplant lymphoproliferative disorders. Br. J. Hematol. 2017, 178, 48-56. [CrossRef]

158. Opelz, G.; Dohler, B. Lymphomas after solid organ transplantation: A collaborative transplant study report. Am. J. Transplant. 2004, 4, 222-230. [CrossRef] [PubMed]

159. O'Connor, J.A.; Cogley, C.; Burton, M.; Lancaster-Weiss, K.; Cordle, R.A. Posttransplantation lymphoproliferative disorder: Endoscopic findings. J. Pediatr. Gastroenterol. Nutr. 2000, 31, 458-461. [CrossRef]

160. Cruz, R.J.; Ramachandra, S.; Sasatomi, E.; Di Martini, A.; de Vera, M.; Fontes, P.; Hughes, C.; Humar, A. Surgical management of gastrointestinal posttransplant lymphoproliferative disorders in liver transplant recipients. Transplantation 2012, 94, 417-423. [CrossRef] [PubMed]

161. Gibson, S.E.; Swerdlow, S.H.; Graing, F.E.; Surti, U.; Cook, J.R.; Nalesnik, M.A.; Lowe, C.; Wood, K.M.; Bacon, C.M. EBV-positive extranodal marginal zone lymphoma of mucosa-associated lymphoid tissue in the posttransplant setting: A distinct type of posttransplant lymphoproliferative disorder? Am. J. Surg. Pathol. 2011, 35, 807-815. [CrossRef] [PubMed]

162. Djokic, M.; Le Beau, M.M.; Swinnen, L.J.; Smith, S.M.; Rubin, C.M.; Anastasi, J.; Carlson, K.M. Post-transplant lymphoproliferative disorder subtypes correlate with different recurring chromosomal abnormalities. Genes 2006, 45, 313-318. [CrossRef]

163. Pitman, S.D.; Huang, Q.; Zuppan, C.W.; Rowsell, E.H.; Cao, J.D.; Berdeja, J.G.; Weiss, L.M.; Wang, J. Hodgkin lymphomalike postratnsplant lymphoproliferative disorder (HL-like PTLD) simulates monomorphic B-cell PTLD both clinically and pathologically. Am. J. Surg. Pathol. 2006, 30, 470-476. [CrossRef] [PubMed] 
164. Soriano-Lopez, D.P.; Alcantar-Fierros, J.M.; Hernandez-Plata, J.A.; Gonzalez-Jorge, A.L.; Velazquez-Ramos, S.; Flores-Hernandez, M.A.; Fuentes, V.; Castaneda, P.; Nieto, J.; Sanchez, J.L.; et al. A scheduled program of molecular screening for Epstein-Barr virus decreases the incidence of post-transplantation lymphoproliferative diseases in pediatric liver transplantation. Transpl. Proc. 2016, 48, 654-657. [CrossRef] [PubMed]

165. Nelson, B.P.; Wolniak, K.L.; Evens, A.; Chenn, A.; Maddalozzo, J.; Proytcheva, M. Early posttransplant lymphoproliferative disease: Clinicopathologic features and correlation with mTOR signaling pathway activation. Am. J. Clin. Pathol. 2012, 138, 568-578. [CrossRef]

166. Reshef, R.; Vardhanabhuti, S.; Luskin, M.R.; Heitjan, D.F.; Hadjiliadis, D.; Goral, S.; Krok, K.L.; Goldberg, L.R.; Porter, D.L.; Stadtmauer, E.A.; et al. Reduction of immunosuppression as initial therapy for posttransplantation lymphoproliferative disorder. Am. J. Transplant. 2011, 11, 336-347. [CrossRef]

167. Choquet, S.; Leblond, V.; Herbrecht, R.; Socié, G.; Stoppa, A.-M.; Vandenberghe, P.; Fischer, A.; Morschhauser, F.; Salles, G.; Feremans, W.; et al. Efficacy and safety of rituximab in B-cell post-transplantation lymphoproliferative disorders: Results of a prospective multicenter phase 2 study. Blood 2006, 107, 3053-3057. [CrossRef]

168. Trappe, R.U.; Dierickx, D.; Zimmermann, H.; Morschhauser, F.; Mollee, P.; Zaucha, J.M.; Dreyling, M.H.; Duhrsen, U.; Reinke, P.; Verhoef, G.; et al. Response to Rituximab induction is a predictive marker in B-cell post-transplant lymphoproliferative disorder and allows successful stratification into Rituximab or R-CHOP consolidation in an International, prospective, multicenter phase II trial. J. Clin. Oncol. 2017, 35, 536-543. [CrossRef] [PubMed]

169. Lindsay, J.; Othman, J.; Heldman, M.R.; Slavin, M.A. Epstein-Barr virus posttransplant lymphoproliferative disorder: Update on management and outcomes. Curr. Opin. Infect. Dis. 2021, 34, 635-645. [CrossRef] [PubMed]

170. Doubrovina, E.; Oflaz-Sozmen, B.; Prockop, S.E.; Kernan, N.A.; Abramson, S.; Teruya-Feldstein, J.; Hedvat, C.; Chou, J.F.; Heller, G.; Barker, J.N.; et al. Adoptive immunotherapy with unselected or EBV-specific T cells for biopsy-proven $\mathrm{EBV}^{+}$lymphomas after allogenic hematopoietic cell transplantation. Blood 2012, 119, 2644-2656. [CrossRef] [PubMed]

171. De Pasquale, M.D.; Mastronuzzi, A.; De Vito, R.; Cometa, A.; Inserra, A.; Russo, C.; De Ioris, M.A.; Locatelli, F. Unmanipulated donor lymphocytes for EBV-related PTLD after T-cell depleted HLA-haploidentical transplantation. Pediatrics 2012, 129, e189-e194. [CrossRef] [PubMed]

172. Jiang, X.; Xu, L.; Zhang, Y.; Huang, F.; Liu, D.; Sun, J.; Song, C.; Liang, X.; Fan, Z.; Zhou, H.; et al. Rituximab-based treatments followed by adoptive cellular immunotherapy for biopsy-proven EBV-associated post-transplant lymphoproliferative disease in recipients of allogeneic hematopoietic stem cell transplantation. Oncoimmunology 2016, 10, e1139274. [CrossRef]

173. Prockop, S.; Doubrovina, E.; Suser, S.; Heller, G.; Barker, J.; Dahi, P.; Perales, M.A.; Papadopoulos, E.; Sauter, C.; Castro-Malaspina, H.; et al . Off-the-shelf EBV-specific T cell immunotherapy for rituximab-refractory EBV-associated lymphoma following transplantation. $J$. Clin. Investig. 2020, 130, 733-747. [CrossRef] [PubMed] 